NBER WORKING PAPER SERIES

\title{
PUBLIC FINANCE AND INDIVIDUAL PREFERENCES OVER GLOBALIZATION STRATEGIES
}

\author{
Gordon H. Hanson \\ Kenneth F. Scheve \\ Matthew J. Slaughter \\ Working Paper 11028 \\ http://www.nber.org/papers/w11028
NATIONAL BUREAU OF ECONOMIC RESEARCH
1050 Massachusetts Avenue
Cambridge, MA 02138
January 2005

For helpful comments we thank Rafaela Dancygier, Jens Hainmueller, Shigeo Hirano, David Stasavage, Michael Tomz, and seminar participants at the Institute for International Economics, London School of Economics, University of Michigan, and University of Oregon. For financial support we gratefully acknowledge the National Science Foundation. The views expressed herein are those of the author(s) and do not necessarily reflect the views of the National Bureau of Economic Research.

(C) 2005 by Gordon H. Hanson, Kenneth F. Scheve, and Matthew J. Slaughter. All rights reserved. Short sections of text, not to exceed two paragraphs, may be quoted without explicit permission provided that full credit, including (C) notice, is given to the source. 
Public Finance and Individual Preferences over Globalization Strategies

Gordon H. Hanson, Kenneth F. Scheve, and Matthew J. Slaughter

NBER Working Paper No. 11028

January 2005

JEL No. F2, H3

\section{$\underline{\text { ABSTRACT }}$}

In the absence of distortionary tax and spending policies, freer immigration and trade for a country would often be supported by similar groups thanks to similar impacts on labor income. But government policies that redistribute income may alter the distributional politics. In particular, immigrants may pay taxes and receive public services. Imports, obviously, can do neither of these. This suggests quite different political coalitions may organize around trade and immigration. In this paper we develop a framework for examining how pre-tax and post-tax cleavages may differ across globalization strategies and also fiscal jurisdictions. We then apply this framework to the case of individual immigration and trade preferences across U.S. states. We have two main findings. First, high exposure to immigrant fiscal pressures reduces support for freer immigration among natives, especially the more-skilled. Second, there is no public-finance variation in opinion over trade policy, consistent with the data that U.S. trade policy has negligible fiscal-policy impacts. Public-finance concerns appear to be crucial in shaping opinions towards alternative globalization strategies.

Gordon H. Hanson

IR/PS 0519

University of California, San Diego

9500 Gilman Drive

La Jolla, CA 92093-0519

and NBER

gohanson@ucsd.edu

Kenneth F. Scheve

Gerald R. Ford School of Public Policy

University of Michigan

412 Lorch Hall

611 Tappan Street

Ann Arbor, MI 48109-1220

scheve@umich.edu
Matthew J. Slaughter

Tuck School of Business

Dartmouth College

100 Tuck Hall

Hanover, NH 03755

and NBER

matthew.slaughter@dartmouth.edu 


\section{Introduction}

Despite the protestations of economists, in many countries a substantial share of the public is skeptical about the benefits of globalization. Concerns stem from many non-economic considerations, from cultural values to beliefs about environmental impacts. But by now, it is also well documented that there are important economic concerns as well; in particular, concerns about labor-market pressures and economic insecurity more generally. ${ }^{1}$ These economic concerns accord with much standard economic theory, in which international flows of goods, capital, and labor all work to integrate national labor markets.

What has received much less attention is the fact that these three alternative strategies of globalization can have quite different economic impacts on national fiscal policies. Immigration and trade, for example, both increase international labor-market competition. Indeed, under certain situations freer trade and immigration can have identical impacts on labor demand and thus labor income. In the absence of distortionary government tax and spending policies, this suggests both strategies would be supported by similar groups.

But fiscal policies that redistribute income may alter the distributional politics. Freer trade and immigration can affect government fiscal activity by comparable amounts, through their similar impacts on labor demand and thus pre-tax labor income. But there may be important fiscal differences between the two. Perhaps most crucially, immigrants may pay taxes, may receive public services, and may vote over tax and spending choices. Imports, obviously, do none of these things. But trade liberalization that lowers tax rates on imports and/or exports may alter the composition and level of tax revenue. This suggests quite different political coalitions

\footnotetext{
${ }^{1}$ See Rodrik (1997, 1998), Scheve and Slaughter (2001a, 2001b, 2001c, 2004), Kessler (2001), O'Rourke and Sinnott (2001, 2003), Hays, Ehrlich, and Peinhardt (Forthcoming), Beaulieu (2002), Baker (2003), Mayda and Rodrik (2004), Mayda (2004), and Jain, Kapur, and Mukand (2004). But also see Citrin, Green, Muste, and Wong (1997) and Hainmueller and Hiscox (2004a, 2004b) for alternative perspectives.
} 
may organize around trade and immigration because of different public-finance considerations, making globalization cleavages more fractious than they might otherwise appear.

Consider the example of the United States. What are the labor-market impacts of freer trade and immigration on U.S. natives? The U.S. comparative advantage in many skill-intensive products means freer trade is likely to lower the pre-tax earnings of less-skilled natives relative to more-skilled natives via the Stolper-Samuelson process (Stolper and Samuelson, 1941). For some time now less-skilled individuals have comprised a large share of U.S. immigrants. In $200031 \%$ of foreign-born adults in the United States had less than 12 years of education, compared with only $13 \%$ of native-born adults. Because low-skilled and high-skilled labor tend to be complements, freer immigration is likely to alter pre-tax earnings of natives like trade does. There is now abundant evidence that freer trade and immigration have in fact generated these pre-tax wage pressures. $^{2}$

But do trade and immigration generate any post-tax impacts through fiscal channels? Freer trade might shift economic activity and thus tax revenue across different states. It might also increase churning in the labor market as workers and firms adjust to changes in relative prices. But the magnitude of additional fiscal costs from this adjustment in countries like the U.S. is likely to be modest, given the limited extent of programs for labor-market adjustment and that trade, unlike immigration, does not change the potential pool of those receiving public assistance. For example, the only U.S. outlay explicitly linked to trade liberalization, Trade Adjustment Assistance, has recently cost less than $\$ 300$ million a year-about $0.01 \%$ of total federal spending in fiscal 2004. Revenue effects from trade liberalization are also likely to be

\footnotetext{
${ }^{2}$ This literature is very large. For studies on trade, see surveys in Feenstra (2000) or Feenstra and Hanson (2002). For important migration studies, see Borjas, Freeman, and Katz (1997), Card (2001), and Borjas (2003).
} 
relatively small in magnitude: the U.S. Constitution prohibits states from taxing trade, and at the federal level trade taxes have recently constituted less than $1 \%$ of total federal revenue. ${ }^{3}$

But in many U.S. states immigrants have access to public assistance financed by taxes. Indeed, there is abundant evidence that immigrants make greater use of means-tested welfare programs than do natives - even after federal welfare reform in 1996 restricted immigrant access to certain government benefits. Freer immigration may thus increase the net tax burden on U.S. natives and thus tend to lower their post-tax income. Progressive tax regimes are common in the United States, which means this fiscal burden may especially hit higher income and more-skilled natives. All this suggests freer immigration is likely to be evaluated by natives for not just its labor-market impacts but its fiscal impacts as well. ${ }^{4}$

To make concrete these fiscal concerns, consider the recent experiences of California and Texas. In the mid-1990s both states had fiscally conservative governors who were rising stars in the Republican party. Pete Wilson and George Bush each faced difficult fiscal environments, as their states had been hit hard by the recession of 1990-91. California and Texas were also absorbing the brunt of the rising national surge of immigration. During the 1990s, as the foreignborn share of the U.S. population grew from $7.9 \%$ to $11.1 \%, 37.3 \%$ of immigrants chose to reside in one of the two states (versus just $17.4 \%$ of natives).

That many new immigrants were poor and relatively likely to receive public assistance created the perception that native taxpayers in the two states were bearing most of the fiscal costs associated with immigration. The data supported this perception. Smith and Edmonston (1997) calculated that in California over 1994-95 immigrants households received an average fiscal

\footnotetext{
${ }^{3}$ Fiscal revenue data come from International Monetary Fund (2004). TAA information comes from Kletzer and Litan (2001).

${ }^{4}$ On immigrant welfare take-up in general see Borjas and Hilton (1996), Borjas (1999), and Fix and Passel (1999). On take-up post-1996 see Zimmerman and Tumlin (1999) and Fix and Passel (2002).
} 
transfer of $\$ 3,463$, or $9.1 \%$ of average immigrant household income, which generated an average fiscal cost to native households of $\$ 1,178$, or $2.3 \%$ of average native household income.

Bush and Wilson appeared to have similar politics. Among other issues, they were both unabashed free traders who strongly supported the North American Free Trade Agreement. Yet they took very different approaches toward immigration. In California, Wilson made restricting public benefits to immigrants the centerpiece of his strategy to control spending. Memorably, he backed Proposition 187, a ballot measure to deny public services to illegal immigrants. ${ }^{5}$ In Texas, Bush embraced the state's immigrant population and courted the Latino vote, saying he would not support a measure like Prop. 187 in Texas. ${ }^{6}$

This tale of two states suggests that fiscal policies shape voter attitudes toward immigration. High-income voters are important Republican constituents in both states. In California, which funds generous public benefits with progressive income taxes, high-income voters may worry immigration raises their tax burden. This was one source of pressure on Wilson to reduce fiscal transfers to immigrants. ${ }^{7}$ Texas, in contrast, has a weaker safety net and no state income tax. Its high-income voters may perceive immigration as having a small impact on their tax obligations, which may have given Bush greater latitude in how to address the issue. ${ }^{8}$

In this paper we examine how fiscal policy may shape individual preferences towards different globalization strategies. We first develop a simple framework of voter preferences, to see how pre- and post-tax cleavages may differ between trade and immigration and also across jurisdictions. Absent distortionary tax and spending policies, standard trade theory predicts that in any country freer immigration and trade will be supported by relatively-abundant workers and

\footnotetext{
${ }^{5}$ See Julie Marquis, “Wilson Blames Ills on Illegal Immigrants," Los Angeles Times, Oct. 17, 1994, B1.

${ }^{6}$ See Juan Palomo, “The Cool Headed Governor," Hispanic Business, Dec. 1995, 12-16.

${ }^{7}$ See Louis Freedberg, "Wilson Defends Stance on Illegals," San Francisco Chronicle, Jun. 23, 1994, A2.

${ }^{8}$ In particular, Texas fiscal policies may have allowed Bush the political space to appear both pro-immigrant, to appeal to the Latino vote, and fiscally conservative, to appeal to the party base. See "Yo te quiero mucho," Economist, Sep. $28,2000$.
} 
opposed by relatively-scarce workers. Again, for many countries there is now abundant evidence of this. But fiscal policies that redistribute income, which have been ignored by the literature, alter the distributional politics along the lines suggested above. Our framework clarifies the preand post-tax pressures on individual economic welfare from various globalization policies.

We then apply this framework to the case of individual immigration and trade preferences across U.S. states over the 1990s. For at least two important reasons this is an especially rich empirical setting. One is the ample evidence for the United States cited above to support both labor concerns that immigration changes wages and fiscal concerns that it raises native tax burdens. The other is that U.S. states vary greatly in the size of their immigration inflows, the generosity of their public benefits, and the progressivity of their tax structures. This variation suggests that natives in some states will be especially "exposed" to immigrant fiscal burdens.

Our empirical work combines data from multiple sources. What results is a rich individuallevel data set with which we can apply our theoretical framework to examine how individual attitudes toward immigration and trade are shaped by important forces including individual labor-market skills and state immigration and fiscal regimes. We exploit variation both across states and over time in fiscal exposure to immigration, such as the fact that some high-immigrant states offer generous public assistance while others do not. Moreover, our data allow us to control for a wide array of individual characteristics and political attitudes that have been demonstrated to have a strong correlation with opinions about trade and especially immigration. ${ }^{9}$

We have two main findings. First, high exposure to immigrant fiscal pressures reduces support for freer immigration among natives, especially the more-skilled. The magnitude of this post-tax fiscal cleavage is comparable to the pre-tax labor-market effects of skill itself. Second,

\footnotetext{
${ }^{9}$ See, for example, Citrin, Green, Muste, and Wong (1997), Scheve and Slaughter (2001a, 2001b, 2001c), Kessler (2001), O’Rourke and Sinnott (2001, 2003), Mayda and Rodrik (2004), Mayda (2004), and Hainmueller and Hiscox (2004a, 2004b).
} 
there is no public-finance variation in opinion over trade policy, consistent with the data that U.S. trade policy has negligible fiscal-policy impacts. The overall message is that public-finance concerns appear to be crucial in shaping opinions towards alternative globalization strategies.

Our paper has five additional sections. In section 2 we develop our theoretical framework. Section 3 presents our data and some motivating summary statistics. In section 4 we discuss our econometric specifications, and in section 5 we report estimation results. Section 6 concludes.

\section{Theoretical Framework: The Welfare Consequences of Immigration and Trade}

In this section we develop a simple framework of voter preferences to examine how pre-tax and post-tax cleavages may differ for trade and immigration and also across jurisdictions. For simplicity, we focus on voter preferences based on just individual economic welfare. As stated in the introduction, there are many important non-economic determinants of attitudes towards globalization. These will be an essential part of our empirical analysis.

Framework

Let $\mathrm{V}\left(\mathbf{p}, \mathrm{I}_{\mathrm{i}}\right)$ be the indirect utility enjoyed by individual $\mathrm{i}$, which depends on the vector of prices for consumption goods and services, $\mathbf{p}$, and also on after-tax income available for consumption, $\mathrm{I}_{\mathrm{i}}$. In turn, after-tax income depends on the pre-tax wage income, $\mathrm{y}_{\mathrm{i}}$; the effective income-tax rate, $\mathrm{t}_{\mathrm{i}}$; and government transfers, $\mathrm{g}_{\mathrm{i}}$.

$$
I_{i}=y_{i}\left(1-t_{i}\right)+g_{i}
$$

Tax rates and government transfers vary across individuals by both state of residence and level of income. Equation (1) assumes both that all income is from labor earnings, and that only labor earnings are taxed. Neither assumption is essential, but they simplify the presentation. 
Together these assumptions imply that an individual's economic well-being can be expressed as $\mathrm{V}\left(\mathbf{p}, \mathrm{y}_{\mathrm{i}}+\mathrm{g}_{\mathrm{i}}-\mathrm{y}_{\mathrm{i}} \mathrm{t}_{\mathrm{i}}\right)$. Thus, well-being can be thought of as depending on three separate terms: prices, p, pre-tax income, $\mathrm{y}_{\mathrm{i}}$, and the post-tax net fiscal transfer, $\left(\mathrm{g}_{\mathrm{i}}-\mathrm{y}_{\mathrm{i}} \mathrm{t}_{\mathrm{i}}\right)$. It is useful to consider the impact of freer immigration or trade on each of these terms separately.

\section{Impacts on Prices}

If immigration lowers some of the prices in $\mathbf{p}$ at which goods and services are available in a state, its individuals are better off. This may be particularly true for non-tradables that use intensively immigrant labor services. As is well-known, freer trade can also alter relative prices, with higher prices for comparative-advantage goods and services.

\section{Impacts on Pre-Tax Labor Income}

Next consider the change in pre-tax labor income, $\mathrm{y}_{\mathrm{i}}$, from freer immigration or trade. If immigration increases the relative supply of low-skilled labor, then this income is likely to rise for high-skilled individuals and fall for low-skilled individuals. We expect the opposite impacts if immigrants are predominantly more-skilled. These wage impacts could be national or local in scope, depending on the extent of labor-market integration across states. And they could even be zero if immigrants are absorbed via mechanisms other than wage changes. ${ }^{10}$

Trade liberalization can also alter individual welfare through (nominal) pre-tax labor income. Indeed, the net impact of this channel plus the commodity-price channel on real labor income is the focus of the Stolper-Samuelson theorem, a well-known mechanism of standard HeckscherOhlin trade theory. Here the net impact on real pre-tax earnings varies along factor lines, not

\footnotetext{
${ }^{10}$ For evidence on national vs. local wage impacts of immigration see Borjas, Freeman, and Katz (1997); Card (2001); and Borjas (2003). Two other adjustment mechanisms may be factor prices other than wages or the industry mix of output, known in the trade literature as Rybczynski effects. See Hanson and Slaughter (2002) for evidence of these output-mix effects across U.S. states. For a more-detailed discussion of all these possibilities, see Scheve and Slaughter (2001c).
} 
industry lines, thanks to sufficient interindustry factor mobility. Impacts on pre-tax income would be different with relatively immobile factors of production. ${ }^{11}$ Impacts on Post-Tax Net Fiscal Transfer

The third channel to consider is the change in the net fiscal transfer received by individual $i$. In countries like the United States this net fiscal transfer, $\left(g_{i}-y_{i} t_{i}\right)$, contains state and federal components. We assume that the federal component can be expressed as a reduced-form function of individual characteristics (e.g., age, income, family size). The state component of net fiscal transfers will depend on the interaction of individual characteristics, as summarized by $y_{i}$, and state tax and spending policies, as summarized by $t_{i}$ and $g_{i}$.

Consider first how immigration will change net fiscal transfers received by natives. For the U.S. case, as stated in the introduction there is now abundant evidence that immigrants make greater use of means-tested welfare programs than do natives. Accordingly, we assume that the arrival of immigrants to a state raises demand and, given eligibility rules, cost for its welfare services. In principle, states can meet this higher immigrant-related cost in one of three ways: borrow, reduce other transfers, or raise tax revenue. In practice, for most U.S. states borrowing is not an option: all but Vermont self-impose constitutional or statutory balanced-budget requirements. We therefore assume that states meet higher immigrant welfare costs by a combination of reduced government transfers to and increased taxation of natives. So with higher immigration natives suffer a fall in $\left(g_{i}-y_{i} t_{i}\right)$ because of lower $g_{i}$ and/or higher $t_{i}$.

The exact fiscal impact on each native in each state will depend on individual characteristics, predominantly labor-market skills and thus income. It will also depend on state characteristics: the nature of state fiscal policy in terms of progressivity and welfare generosity, and the

\footnotetext{
${ }^{11}$ See Scheve and Slaughter (2001b) for details on trade's impact on factor income in different settings.
} 
magnitude of the state's total immigrant inflow. We expect natives to experience larger falls in net fiscal transfers when living in states with larger immigrant inflows and/or generous welfare programs. For states that use more progressive tax and spending systems, we also expect the declines in net fiscal transfers to fall disproportionately on more-skilled natives.

Now consider the fiscal impacts of freer trade. Like freer immigration, freer trade can alter $\left(g_{i}-y_{i} t_{i}\right)$ via pre-tax changes in $y_{i}$. Unlike freer immigration, however, freer trade does not bring a change in the population and thus changes in welfare take-up that must be accommodated by changes in the net fiscal transfers to natives. It is true that trade might increase churning in the labor market as workers and firms adjust to changes in relative prices. But the magnitude of additional fiscal costs from this adjustment in countries like the U.S. is likely to be modest, given the limited extent of state and federal programs for labor-market adjustment. ${ }^{12}$ We conclude that freer trade generally does not generate the same fiscal pressures as immigration, and certainly does not do so in countries with minimal trade taxes and minimal labor-market policies. ${ }^{13}$

\section{Summary of Theoretical Framework}

Freer immigration and welfare can affect individual economic welfare and thus policy preferences through product prices, pre-tax labor income, and post-tax net fiscal transfers. Public-opinion research to date has largely ignored this third channel. Our framework clarifies that for immigration this channel is likely important but that for trade its relevance depends on whether trade and fiscal policies are explicitly linked, which is not the case in the United States.

\footnotetext{
12 An alternative argument may be that a generous tax and transfer system that provides more insurance to workers reduces opposition to liberalization. For cross-country evidence consistent with this idea, see Hays, Ehrlich, and Peinhardt (forthcoming) and Scheve and Slaughter (forthcoming). This effect may be relevant in settings in which borrowing is allowed or for which the incidence of taxes paying for the insurance is not clear-settings unlike the U.S. states. Or this effect may especially apply to less-skilled individuals at greater risk from liberalization but less likely to pay the costs. Our empirical work investigates the possibility of this alternative fiscal impact.

${ }^{13}$ Today in many countries trade taxes constitute a small share of total government revenue. This is not true for many other countries, however, especially outside the OECD, and was not true for almost all of today's advanced countries in earlier decades and/or centuries. For a discussion see United States Trade Representative (2003).
} 
Our framework generates a number of testable predictions of how immigration and trade opinions in the United States may differ across individuals and also across fiscal jurisdictions. The pre-tax labor-income pressures from immigration and also trade are likely to cleave across skill groups within all jurisdictions. But for immigration there should also be after-tax fiscal pressures that vary with state fiscal regime and skill type. Natives in states that are fiscally exposed to immigration, thanks to a combination of high immigrant inflows and/or generous welfare programs, should be less supportive of immigration than natives in less-exposed states. To the extent that states rely on progressive tax-and-spending regimes, this reduced support for freer immigration should be especially strong among higher income and more-skilled natives.

\section{Data and Summary Statistics}

The data for our analysis of individual policy preferences about immigration and trade come from three sources. We measure individual attitudes regarding immigration and international trade using the 1992 and 2000 American National Election Studies (NES) (Sapiro, et al, 1998). We select these two NES years to match as closely as possible our data from the 1990 and 2000 U.S. Censuses of Population and Housing, from which we obtain data on immigrant and native populations, labor forces, and use of public assistance, and also to allow for significant temporal variation in these characteristics. Finally, data on state fiscal policies, in particular welfare spending and tax progressivity, come from the U.S. Censuses of Governments.

\subsection{The Fiscal Impact of Immigrant Populations in U.S. States}

We begin our discussion of the data by showing that the fiscal impact of immigration varies significantly across U.S. states. States vary both in their exposure to immigration and in their generosity of public assistance. In summarizing immigration patterns across U.S. states, we take 
households (rather than individuals) as the unit of analysis. Households are the units on which government agencies assess income taxes, property taxes, and other levies. For determining individual eligibility for means-tested benefit programs, it is typically household characteristics that are evaluated (Zimmermann and Tumlin, 1999). An immigrant household is defined as one whose head is foreign born. This definition of the immigrant population includes U.S.-born children of immigrants.

Figure 1, which plots the share of the state population residing in immigrant-headed households in 1990 and 2000, reproduces the familiar fact that within the United States the immigrant population is geographically concentrated. For the nation as a whole, the share of the population living in immigrant-headed households was $16.5 \%$ in 2000, up from $11.5 \%$ in 1990 . For 2000 the immigrant population share was between $30 \%$ and $40 \%$ in two states (California, New York), and it was above the national share in just eleven other states. ${ }^{14}$

While California and New York have long been immigrant havens, the immigrant population has been growing most rapidly in states that traditionally have not been immigrant gateway locations. To see this growth, it is important to control for the facts that some states begin with very small immigrant populations and that some have rapid growth in native populations. For immigrants and natives, we normalize state population growth by the cross-time average state population and measure immigration population growth relative to native population growth as,

$$
\frac{\mathrm{M}_{2000}-\mathrm{M}_{1990}}{\frac{1}{2}\left(\mathrm{M}_{2000}+\mathrm{M}_{1990}\right)}-\frac{\mathrm{N}_{2000}-\mathrm{N}_{1990}}{\frac{1}{2}\left(\mathrm{~N}_{2000}+\mathrm{N}_{1990}\right)}
$$

where $\mathrm{M}_{\mathrm{t}}$ and $\mathrm{N}_{\mathrm{t}}$ are the year $\mathrm{t}$ foreign-born and native-born populations in a state, respectively.

\footnotetext{
${ }^{14}$ These 11 states are New Jersey, Hawaii, Florida, Nevada, Texas, Connecticut, Massachusetts, Arizona, Rhode Island, Illinois, and District of Columbia.
} 
Figure 2 plots normalized relative immigrant population growth between 1990 and 2000 against the immigrant population share in 1990. The states with the most rapid immigrant population growth (North Carolina, Georgia, Arkansas, Nebraska, Colorado, Utah) had relatively small immigrant populations in 1990. Other states with rapidly growing immigrant populations (Nevada, Colorado, Utah, Oregon, Arizona) had moderate immigrant populations in 1990. These two groups of states had rapid job growth during the 1990s. And, with the exception of Oregon, these states are not known for the generosity of their welfare programs.

The fiscal impact of immigrants is, however, only partially related to the size of immigrant flows. Depending on both immigrants' characteristics and state policies, immigrants may or may not access public assistance or consume other public services and may or may not pay taxes. The extent of fiscal transfers from natives to immigrants depends on these factors as well.

Individuals use public services in many forms, including public safety (fire and police protection), public spaces (parks and recreation facilities), public education, public health care, and public assistance (welfare). For immigrants, it is access to public assistance that is perhaps the most controversial. The Census of Population and Housing collects information on cash assistance in the form of supplemental security income, aid for families with dependent children (which has become temporary assistance for needy families), and general assistance. This is only a partial list of means-tested entitlement programs, and it excludes non-cash benefits such as food stamps, Medicaid, public housing, and energy subsidies. In contrast, the Census of Governments data discussed below measures both cash and non-cash benefits.

Figures $3 \mathrm{a}$ and $3 \mathrm{~b}$ plot the fraction of immigrant and native households that received cash public assistance in 1990 and 2000. The likelihood that immigrants receive welfare varies widely across states. The states in which immigrants were most likely to receive benefits are 
mostly high-income states on the east and west coasts (California, New York, Massachusetts, Pennsylvania, Connecticut). In 1996 there was a major reform of federal U.S. welfare law, which imposed a lifetime cap on the number of years an individual could receive certain cash benefits and which excluded non-citizens from eligibility for many types of benefits. After 1996 many states at least partially replaced benefits at the state level that immigrants lost at the federal level, adding to the cross-state variation of public benefits available to immigrants. ${ }^{15}$

As discussed in Section 2, an important requirement of our analysis below will be to measure accurately variation in natives' potential fiscal exposure to immigrants across both states and years. Our measure would ideally account for the relative size of the immigrant and native populations as well as the incidence and value of immigrant uptake of benefits. Figure 3 shows immigrant uptake incidence, but only for cash benefits and without any value information. The Census of Governments measures the annual value of both cash and non-cash benefits by state, but not broken out between immigrants and natives. However, Figure 3 shows a positive correlation between the fraction of native and immigrant households receiving public assistance (0.24 in 2000 , weighted by state population), which suggests that welfare spending in total should be a reasonable proxy for welfare spending on immigrants only.

Accordingly, our first measure of potential fiscal exposure to immigrants, Fiscal Exposure 1, is a dichotomous indicator variable equal to one for state-years that meet two conditions: (1) that have relatively high welfare generosity, measured as above the national median welfare spending per native; and (2) that have relatively high immigration populations defined as those states with

\footnotetext{
${ }^{15}$ For evidence on this replacement, see Zimmermann and Tumlin (1999). Following welfare reform, there was a welldocumented national decline in the fraction of native and immigrant households receiving benefits from means-tested entitlement programs (Fix and Passel, 2002; Borjas, 2003). The national decline was larger for immigrants than for natives, leading many to conclude that welfare reform was at least partly effective in its stated aims. Borjas (2003) finds that the national relative decline in immigrant use of means-tested programs was due entirely to California. For the period 1994-1998, he finds that outside of California immigrant and native use of welfare declined by a similar amount.
} 
a ratio of immigrants to natives of at least $0.12 .{ }^{16}$ Our welfare-spending measure from the Census of Governments includes a broad range of benefits including cash and medical assistance.

An alternative measure of native fiscal exposure might use the immigrant uptake intensity in Figure 3 but scale it against all native households to measure the overall native tax base. The result is Figures $4 \mathrm{a}$ and $4 \mathrm{~b}$, which plot the number of immigrant households receiving cash benefits relative to the total number of native households against the ratio of immigrant to native households for 1990 and 2000, respectively.

Many states have both small immigrant populations and small numbers of immigrant households on welfare. Among high-immigration states there is considerable variation in immigrant uptake of welfare. California and New York stand out as states with high immigrant welfare use. Among states with immigrant households equal to $10 \%$ to $20 \%$ of the number of native households in 1990 , the ratio of welfare-receiving immigrant households to native households ranges from 0.005 in Nevada to over 0.02 in Massachusetts. Although the relative size of the immigrant population is comparable in these two states, in effect each native household in Massachusetts must support four times as many immigrant households on welfare as does each native household in Nevada.

This cross-state variation in the expected fiscal cost to natives of immigrant welfare use creates the potential for regional variation in public opinion about immigration policy-even among states with similar-sized immigrant populations. Accordingly, we construct our second measure, Fiscal Exposure 2, as a dichotomous indicator variable equal to one for state-years in

\footnotetext{
${ }^{16}$ This particular cutoff identifies those states in Figure 1 that are spread out from the mass of states in the bottom left with low immigrant populations in both years.
} 
which the ratio of immigrant households receiving cash forms of welfare relative to the total number of native households exceeds $0.012 .^{17}$

This ratio that defines Fiscal Exposure 2 gauges the potential fiscal effects of immigrants on natives insofar as it incorporates both the incidence of immigrant cash welfare use and also the relative sizes of the immigrant and native populations. Relative to Fiscal Exposure 1, Fiscal Exposure 2 has the disadvantages of excluding non-cash benefits and also containing no measure of the value of welfare use. We thus prefer our first measure, but for robustness use both.

\subsection{Public Opinion about Globalization and State Generosity Towards Immigrants}

The NES is an extensive survey of individual political opinions, including opinions about trade and immigration, based on a stratified random sample of the U.S. population. These surveys also report respondent characteristics including age, gender, educational attainment, and location of residence. To evaluate individual preferences toward immigration and trade, we use two questions from the NES. Regarding immigration, the NES asks

"Do you think the number of immigrants from foreign countries who are permitted to come to the United States to live should be increased a little, increased a lot, decreased a little, decreased a lot, or left the same as it is now?"

For the main analyses of immigration in the paper, we set the variable Immigration Opinion equal to 1 for those individuals favoring immigration to be decreased a little or a lot and 0 for those individuals favoring immigration be maintained or increased. ${ }^{18}$ This question requires respondents to reveal their general position on the proper direction for U.S. immigration policy. ${ }^{19}$ In $2000,44.8 \%$ of respondents favored decreasing immigration $(15.0 \%$ by a little, $29.8 \%$ by a

\footnotetext{
${ }^{17}$ The threshold of 0.012 was selected based on Figure 4a. Along the y-axis of this graph, there is a substantial gap between Texas and the states above it separated by 0.012 .

${ }^{18}$ Using the fully disaggregated coding of the responses to this question and changing our econometric specifications accordingly generates qualitatively similar results. We dichotomize this variable for ease of exposition and comparison to trade opinions.

${ }^{19}$ The question does not ask what skill-mix immigrants would have relative to the survey respondent or the native population as a whole. We assume responses are informed by the average skills of actual U.S. immigrants in recent decades, which are relatively low and thus increase the relatively supply of less-skilled workers. The distribution of U.S. immigrants does include a substantial number of relatively skilled individuals. Nonetheless, the average U.S. immigrant is less skilled and we assume that this central tendency informs respondents' answers to the question.
} 
lot), $44.5 \%$ favored leaving immigration unchanged, and 9.8\% favored increasing immigration (5.8\% by a little, $4.0 \%$ by a lot).

Regarding trade, the NES asks,

"Some people have suggested placing new limits on foreign imports in order to protect American jobs. Others say that such limits would raise consumer prices and hurt American exports. Do you favor or oppose placing new limits on imports, or haven't you thought much about this?"20

We set the variable Trade Opinion equal 1 for those individuals favoring protection and 0 for those opposing it. This question requires respondents to reveal their general position on U.S. trade policy. Note that the question does not ask what sector(s) would receive import restrictions. We assume that responses to the question are informed by the idea that import limits will be placed on comparative-disadvantage sectors. This seems more sensible than alternatives such as limits on comparative-advantage sectors. In $2000,48.5 \%$ of respondents favored new restrictions on imports.

Our theoretical discussion in Section 2 focused on two motivations for opposition to immigration and trade. One is the concern that immigration and trade put downward pressure on pre-tax wages for less-skilled workers. A number of recent papers have found evidence consistent with this prediction. ${ }^{21}$ Our focus is on the second motivation: concern that immigrant use of public services alters the net fiscal burden on native taxpayers. This carries potential after-tax impacts of immigration; in particular, the progressive U.S. tax structure could tend to make high-income taxpayers particularly more opposed to immigration. Recall that because U.S. trade policy does not have the same fiscal consequences as immigration, we do not expect

\footnotetext{
${ }^{20}$ In 2000, the NES asked some respondents this question and some respondents a similar but not identical question which did not include the response option "haven't you thought much about this". In the main trade results reported in Table 10, we include all respondents from the 2000 survey who answered either form of the question. The results are qualitatively the same if those respondents asked the experimental question are excluded from the analysis.

${ }^{21}$ Scheve and Slaughter (2001a, 2001b, 2001c), Kessler (2001), O’Rourke and Sinnott (2001, 2003), Mayda and Rodrik (2004), Mayda (2004), and Hays, Ehrlich, and Peinhardt (Forthcoming). But also see Citrin, Green, Muste, and Wong (1997), and Hainmueller and Hiscox (2004a, 2004b) for alternative perspectives.
} 
support for trade policy to vary across states according to expected welfare costs of immigrants or even by alternative measures of fiscal exposure tailored to trade as opposed to immigration.

Our econometric estimation will examine both these motivations, as well as a host of other important non-economic factors that may affect an individual's stance on immigration, e.g., political beliefs and ethnicity. But before turning to these estimates, it is instructive to see if simple summary statistics reveal patterns consistent with these two considerations.

Table 1 shows the fraction of native-born individuals favoring new restrictions on immigration in the 1992 and 2000 NES surveys by four levels of education (less than high school, high school, some college, and college graduate). The most educated are the least opposed to immigration, broadly consistent with the expectation that less-skilled natives have more restrictionist policy opinions due to labor market competition. For these pooled descriptive statistics, Table 1 indicates that the key skills cleavage is between college graduates and all other respondents. Table 2 reproduces Table 1 for trade policy opinions. Support for trade restrictions varies dramatically by skill type. Over $72 \%$ of individuals without a high-school diploma support further restrictions, compared with just $39 \%$ of college graduates.

Table 3 breaks down Table 1 further according to whether an individual lives in a state for which the welfare costs of immigrants are expected to be high or low as measured by Fiscal Exposure 1 and 2. Given our theoretical framework, the key fiscal quantity of interest is the difference in the immigration opinions of similarly skilled respondents across states. In states with high fiscal exposure to immigration we expect natives to be less supportive of freer immigration than are natives elsewhere. To the extent that states rely on progressive tax-andspending regimes, this reduced support should be especially strong among more-skilled natives, 
for whom the negative fiscal effects of immigration on after-tax income work against the positive wage effects of immigration on pre-tax labor income.

Table 3 shows that in states with high expected fiscal costs $42 \%$ to $44 \%$ of college graduates have restrictionist immigration opinions, compared with only $36 \%$ in states with low expected costs. This differential is even larger for high-school dropouts, somewhere between nine and 16 percentage points. These cross-state cleavages are broadly consistent with the idea that fiscal concerns reduce support for immigration among U.S. natives.

Table 4 investigates whether the patterns of Table 3 hold for trade policy opinions. Again, because U.S. trade policy does not have the same fiscal consequences as immigration we do not expect support for freer trade to vary across U.S. states according to the welfare costs of immigrants. The pattern of responses in Table 4 is broadly consistent with this expectation. For the three lower education levels trade opposition is lower in the high fiscal-exposure states; for college graduates trade opposition is higher in these states, but marginally so. ${ }^{22}$

\section{Empirical Specifications}

Our theoretical discussion highlighted three distinct channels through which immigration and trade are likely to affect an individual's economic well-being: prices, pre-tax income, and posttax net fiscal transfers. We build on this framework to specify reduced-form estimating equations for individual preferences regarding immigration and trade policy.

Let $I_{i s t}^{*}\left(T_{i s t}^{*}\right)$ be a latent variable indicating opposition to immigration (trade) by a native individual $i$ living in state $s$ at time $t$. We model the determinants of $I_{i s t}^{*}\left(T_{i s t}^{*}\right)$ as follows,

$$
I_{i s t}^{*}=\alpha_{0}+\beta_{j} 1\left(E d u c_{i s t j}\right)+\gamma_{k} 1\left(E d u c_{i s t k}\right) 1\left(\operatorname{Imm}_{s t}\right)+\lambda_{k} 1\left(E d u c_{i s t k}\right) 1\left(F E_{s t}\right)+\theta X_{i s t}+\delta Z_{s t}+\mu_{i s t}
$$

\footnotetext{
${ }^{22}$ In the econometric analyses of trade opinion presented below, we also examine alternative measures of fiscal exposure that are tailored to trade as opposed to immigration.
} 
where $j$ is an index from 1 to $3 ; k$ is an index from 1 to $4 ; 1\left(E d u c_{i s t j}\right)$ and $1\left(E d u c_{i s t k}\right)$ are a series of dichotomous variables indicating individual educational attainment; $1\left(\operatorname{Imm}_{\text {st }}\right)$ is the dichotomous variable Immigration indicating whether the state in which the respondent lives is a high-immigration state; $1\left(F E_{s t}\right)$ is a dichotomous variable, Fiscal Exposure 1 or 2, indicating whether the state in which the respondent lives faces a high level of fiscal exposure to immigration; $\mathrm{X}$ is vector of individual-level control variables, $\mathrm{Z}$ is a vector of state-level control variables; $\alpha, \beta, \gamma, \lambda, \theta$, and $\delta$ are parameters to be estimated; and $\mu_{\text {ist }}$ is a mean-zero random error term that reflects unobserved factors associated with individual preferences over changes in immigration or trade policy, including the impact of immigration or trade on the unobserved determinants of wage income and fiscal transfers.

The first term in this expression, $\alpha_{0}$, is simply a constant. The second and third terms evaluate the pre-tax income channel for how immigration and trade affect economic well-being. The second term is indexed by $j$ because for $1\left(E d u c_{i s t j}\right)$ we include three indicator variables, High School, Some College, and College, with No High School as the omitted category. The third term is indexed by $k$ because we interact all four educational categories with the variable Immigration, indicating whether the respondent lives in a high immigration state.

This parameterization provides a pre-tax labor-market interpretation of $\beta_{1 \ldots 3}$ and $\gamma_{1 \ldots 4}$. In the presence of low-skilled immigration, we expect opposition to immigration to be decreasing in respondent skill levels because of its effect on earnings across skills. Thus the coefficient for College, $\beta_{3}$, should be less than zero, and perhaps the same will hold for Some College, $\beta_{2}$. If immigrants alter wages locally rather than nationally, then correlations between skills and opinion should be stronger in states with immigration levels. This implies that the coefficient on 
the interaction between No High School and Immigration, $\gamma_{1}$, should be greater than zero and/or that the coefficient on the interaction between College and Immigration, $\gamma_{4}$, should be less than zero (with potentially analogous predictions for the other two education-immigration interactions). With the exception of the last point of local wage impacts, these same predictions apply to trade insofar as freer trade expands the effective supply of low-skilled labor.

The fourth term in equation $2, \lambda_{k} 1\left(E d u c_{i s t k}\right) 1\left(F E_{s t}\right)$, evaluates the main argument of this paper: that the consequences of immigration for post-tax net fiscal transfers have an important effect on individual economic well-being and thus policy opinions. We interact all four educational variables with our measures indicating whether the state in which the respondent lives faces high fiscal exposure to immigration. Our theoretical discussion highlighted the consequences of immigration for net fiscal transfers across different income groups. But for our benchmark specifications, we use education rather than income to differentiate fiscal exposure across individuals in the same state. This is because income is well known to be poorly measured, nonrandomly missing in surveys, and sensitive to transitory shocks (e.g., illness or bonuses) that do not reflect permanent income and thus fiscal status. For robustness, we will also present evidence using a direct measure of each respondent's relative income.

The parameters $\lambda_{1 \ldots 4}$ indicate whether respondents with No High School, High School, Some College, and College in high fiscal-exposure states are more or less likely to oppose immigration. Our theoretical discussion suggests that respondents across all income/educational categories should be more opposed to immigration in states with high fiscal exposure to immigrants, and that this should be especially true for high income/educated individuals due to the progressivity of state tax and transfer systems. We therefore expect the parameters $\lambda_{1 \ldots 4}$ to be positive and increasing in magnitude. In principle, a similar effect might be observed for trade. But in 
practice, we do not expect opposition to trade to vary significantly with state fiscal exposure because of the small magnitudes of any likely fiscal effects of trade in the context of U.S. states.

Finally, the fifth and sixth terms in equation (2), $\theta X_{\text {ist }}$ and $\delta Z_{\text {st }}$, estimate the effect of various individual-level and state-level control variables including Age, Age Squared, dichotomous indicator variables Female and Hispanic, State Unemployment, a year indicator variable for 2000, and in most specifications a full set of state fixed effects to account for time-invariant features of states that may influence individual attitudes towards immigration and trade. Some of these control variables account for the price channel, which depends on consumption patterns not measured in our data. ${ }^{23}$ Importantly, the controls may capture some non-economic influences on policy opinions. We will report results with many additional control variables that measure tolerance, isolationist sentiment, ideology, and partisanship, all which more directly attempt to account for non-economic determinants of policy opinions.

In equation (2), the latent variable $I_{\text {ist }}^{*}\left(T_{i s t}^{*}\right)$ is unobserved. Let $I_{\text {ist }}$, Immigration Opinion, ( $T_{\text {ist }}$, Trade Opinion) be an indicator variable equal to one if an individual favors decreasing immigration (restricting trade) and zero otherwise, in which case $\operatorname{Pr}\left(I_{\text {ist }}^{*}>0\right)=\operatorname{Pr}\left(I_{\text {ist }}=1\right)$ or $\operatorname{Pr}\left(T_{i s t}^{*}>0\right)=\operatorname{Pr}\left(T_{\text {ist }}=1\right)$. Assuming that the idiosyncratic component of individual preferences, $\mu_{\text {ist }}$ is normally distributed, then for immigration (analogously for trade) the following applies:

$$
\operatorname{Pr}\left(I_{\text {ist }}=1\right)=\Phi\left(\alpha_{0}+\beta_{j} 1\left(E d u c_{i s t j}\right)+\gamma_{k} 1\left(E d u c_{i s t k}\right) 1\left(I m m_{s t}\right)+\lambda_{k} 1\left(E d u c_{i s t k}\right) 1\left(F E_{s t}\right)+\theta X_{i s t}+\delta Z_{s t}\right)
$$

where $\Phi()$ is the standard normal cdf. We will estimate equation (3) as a probit, first on immigration and then on trade preferences and report robust standard errors clustered on states.

\footnotetext{
${ }^{23}$ The interactions between educational attainment and whether the respondent lives in a high-immigration state also control for the price channel because consumption patterns vary by income and education and because the effect of immigration on prices depends on how many immigrants there are.
} 
All estimations use NES data for native-born individuals pooled across 1992 and 2000. We focus on the sub-sample of natives to highlight the public-finance aspect of preference formation.

\section{Estimation Results}

\subsection{Immigration-Policy Preferences}

Table 5 reports our benchmark estimates of equation (3) for immigration preferences. Again, our theoretical framework suggests that freer immigration may affect individual economic welfare through three distinct channels. One is through commodity prices, captured with our benchmark controls, state fixed effects, and other regressors. The second is through pre-tax labor income. This is measured by the dichotomous skill indicators (No High School, High School, Some College, and College) and these indicators interacted with Immigration, our dichotomous indicator of high state immigration presence. These interactions allow the laborincome consequences of - and thus policy preferences over-immigration to be different in high-immigration states. ${ }^{24}$ The third channel is through after-tax net fiscal transfers. This is measured by Fiscal Exposure 1 and 2, interacted with the skill regressors. Each specification includes the set of benchmark controls discussed in Section 4 and we estimate specifications both without and with state fixed effects. We prefer including state fixed effects because there are likely to be unobserved, unmeasured but time constant characteristics of states that both may influence support for immigrants and also may be correlated with our fiscal-exposure measures. $^{25}$

\footnotetext{
${ }^{24}$ Consistent with much of the labor-economics literature on wage impacts from immigration, this specification assumes that states delineate local labor markets. Our key results demonstrating the importance of public-finance considerations for public opinion about immigration policy are robust to dropping the interactions between education and Immigration, which would be consistent with immigration having national and not state-level wage impacts.

${ }^{25}$ For brevity, estimation results for all of these other regressors are omitted from the tables.
} 
We first note that the results across all four specifications in Table 5 replicate the finding in the literature that more-skilled natives are less likely to support immigration restrictions. The coefficients on education alone indicate the relationship between education and immigration opinions for respondents in states for which immigration is low in both magnitude and expected fiscal effects. Here, opposition to immigration is weakest among college graduates. The coefficient on College in Model I2 implies that college graduates were approximately 14 percentage points less likely to prefer fewer immigrants than high-school dropouts. ${ }^{26}$

The results for respondents in high-immigration but low-fiscal-impact states show even more striking evidence of this skills cleavage. For both fixed-effects specifications, the coefficient on the interaction between No High School and Immigration is positive, large in magnitude, and statistically significant (none of the other skill interactions with Immigration are significant). Low-skilled respondents have substantially stronger support for further immigration restrictions in those states for which immigration is high but fiscal exposure is low. More precisely, since this result is clearest in the specifications with fixed effects, it is in those states with increasing levels of immigrants that low-skilled natives are most supportive of restrictions. This finding is consistent with area-analysis models that predict stronger labor-market consequences of immigration in gateway communities, and so that differences in policy opinions across skill groups are likely to be larger in magnitude. ${ }^{27}$ The results for Model I 2 imply that the difference in probability of supporting tighter immigration policies between College and No High School natives doubles in size in those states with high immigration populations, to a difference of over

\footnotetext{
${ }^{26}$ The size of this effect is very similar across all four specifications. We note that for respondents in these states we do not observe the expected differences between the No High School, High School, and Some College groups. There is some evidence (Models I3 and I4) that individuals with (i.e., not without) a high-school degree have the most-restrictionist opinions.

${ }^{27}$ Scheve and Slaughter (2001c) found little support for the prediction that policy opinion differences between more and lessskilled workers are strongest in gateway communities. The analysis in this paper takes advantage of a longer time period between surveys in order to estimate specifications with state fixed effects that account for unobserved state characteristics and identify off of changes in immigration population.
} 
30 percentage points. This cleavage is consistent with the potential impact of immigration on pre-tax labor income being an important factor in opinion formation over immigration policy.

Our main substantive question of interest, however, is whether potentially high fiscal costs from immigration shape policy preferences. Our theoretical framework suggested that this effect may hold across all natives, but is likely to be strongest for those with the highest skills and income. Across all four specifications in Table 5, the coefficients on interactions between College and Fiscal Exposure 1 (or 2) are positive and statistically significant. College-educated natives have more-restrictionist policy views in states for which the net fiscal burden of immigration is likely to be high. Table 5 also offers evidence of a fiscal effect for the other skill categories as well. Our preferred specification in Table 5 is Model I2, which uses Fiscal Exposure 1 (rather than 2) and includes (rather than excludes) state effects. In Model I2 the interaction of Fiscal Exposure 1 with each of the four skill measures is positive and statistically significant (though only marginally so for the No High School interaction).

These results for the fiscal-exposure regressors are consistent with the central argument of this paper: the post-tax fiscal burdens associated with more immigrants tend to increase support for immigration restrictions, and do so even among those more-skilled individuals likely to benefit in the labor market from immigration. These results are the paper's main finding.

The substantive magnitude of the fiscal-exposure effect is large. For the preferred fixedeffects specifications reported in Table 5, Table 6 reports the estimated effect across different skill groups of increasing fiscal exposure to immigration on the probability of supporting immigration restrictions. For Fiscal Exposure 1, moving a college graduate from a state with low to high fiscal exposure to immigration raises the probability of favoring fewer immigrants by 19 percentage points. The size of the comparable effect for natives in the other three educational 
categories is about 10 percentage points. The magnitude of this post-tax fiscal cleavage is comparable to the magnitude of the pre-tax labor-market cleavage across skills mentioned above. For Fiscal Exposure 2 the results are almost identical in magnitude for college graduates but are smaller and less precisely estimated for the other skill categories. We conclude from our benchmark results in Tables 5 and 6 that living in states with high fiscal costs from immigration significantly increases the likelihood of restrictionist opinions, and that the magnitude of this fiscal cleavage is large and in fact comparable in size to the labor-market cleavage across skills.

To evaluate the robustness of our benchmark results and also probe our interpretation of them, we estimated many alternative specifications. Some of these are reported in Tables 7 through 9. The two specifications in Table 7 add to our benchmark fixed-effects models a broader set of demographic and political control variables. The estimates for these additional control variables are mostly consistent with previous findings in the literature. For example, respondents that scored higher on our measure of Tolerance were less likely to have restrictionist opinions about immigration policy. Individuals with isolationist views about the role of the United States in the world, as measured by Isolationism, were much more likely to support further immigration restrictions. These findings highlight the common claim in the literature that policy attitudes about immigration are shaped in part by non-economic considerations (e.g. Citrin et al 1997, Scheve and Slaughter 2001c, Hainmueller and Hiscox 2004a). ${ }^{28}$ We would add that these non-economic considerations provide a complementary answer to our emphasis on fiscal considerations in addressing why individuals might have different opinions about alternative

\footnotetext{
${ }^{28}$ This interpretation needs, however, to be made cautiously. It is, of course, possible that factors such as levels of tolerance, ideology, and isolationist sentiments are a consequence of economic competition rather than exogenous determinants, though a completely economic reductionist account seems implausible. Moreover, a number of the additional control variables may be endogenous to immigration policy opinions or generate other estimation problems such as introducing additional measurement error. For these reasons, we retain our benchmark specifications in most of the remaining results discussed in the paper.
} 
globalization strategies. Certainly one reason why is that prejudice and other political attitudes are likely to play a bigger role in policies like immigration in comparison to policies like trade.

Rather than explore the results for these control variables in greater detail, we focus on the robustness of our key fiscal findings for these specifications. For both Models I5 and I6, the key fiscal-exposure estimates remain statistically and substantively significant. If anything, results come through more clearly with the additional controls: now the interaction terms of Fiscal Exposure 2 with High School and Some College are also significantly different from zero. ${ }^{29}$

In Table 8 we experiment with alternative measures of individual skills and relative fiscal position. Consistent with much work in labor economics, our benchmark specifications measure individual skills and relative fiscal position with educational attainment. This latter choice assumes that long-run or "permanent" income is determined primarily by human capital. That said, it is certainly an individual's realized income rather than educational attainment that directly determines net fiscal transfers and their possible sensitivity to immigrant inflows. But as discussed earlier, for our benchmark specifications we chose education rather than income.

In Table 8 we replace individual educational attainment with individual reported income ranked by quartiles; we retain the other aspects of the benchmark specification. Our key fiscal results are qualitatively the same as those in Table 5. For both measures of fiscal exposure to immigration, the interaction terms with all income quartiles are positive. For both fiscal measures the estimate is largest and statistically significant for the highest income quartile. And for Fiscal Exposure 1 the estimate is significant for the third quartile and marginally so for the

\footnotetext{
${ }^{29}$ To further test the robustness of the correlation between fiscal exposure and policy opinions to the inclusion of additional control variables, we estimated a number of alternative specifications that added further measures of attitudes toward minority groups. In all specifications, the results were qualitatively similar to those reported in Table 7 . In some specifications, the interaction terms between High School and Some College with the fiscal exposure variables were no longer significant at conventional levels but in all cases the interaction terms with the College variable were statistically and substantively significant.
} 
second. Overall, these results are consistent with argument that respondents more exposed to the tax and transfer consequences of immigration have more restrictionist immigration opinions. ${ }^{30}$

The final set of immigration results are in Table 9, where we explore our interpretation of the key fiscal-exposure results. Our theoretical framework emphasized that the fiscal impact of immigration may affect natives of all skill and income groups. But since most state tax and transfer systems are at least somewhat progressive, the impact of immigration on net fiscal transfers is likely to hit hardest the most-skilled, highest-income natives. Evidence consistent with this argument has been presented in terms of the magnitude of the effect of fiscal exposure across different skill (and, in Table 8, income) categories.

This interpretation can be bolstered by re-estimating our benchmark specifications on the sub-sample of natives living in states with the most-progressive tax systems. We identify these states with two measures. The first indicates all states with above-median values of the ratio of the top income-tax rate to the bottom rate. The second indicates all states with above-median values of the ratio of income tax revenue to total revenue. Based on our theoretical framework, we expect that the pattern of estimates for the consequences of increasing fiscal exposure on restrictionist immigration will be most clear in those states that match our theoretical assumption of relatively progressive tax and transfer systems.

The results reported in Table 9 confirm this expectation, where we use our preferred Fiscal Exposure 1. The most striking difference between these results and those in Table 5 for the full sample is that the magnitude of the impact of living in a state with high fiscal exposure to immigration is now much larger for these sub-samples of states with relatively progressive tax systems. For example, for the model using our first measure of progressive states, moving a high-school graduate from a state with low to high fiscal exposure to immigration raises the

\footnotetext{
${ }^{30}$ These results employing income quartiles are also robust to including the additional control variables discussed in Table 7.
} 
probability of favoring fewer immigrants by 15 percentage points-versus just 6 to 12 percentage points in the full-sample estimates of Table 5. For this same model, for college graduates the impact of living in a state with high rather than low fiscal exposure is over 30 percentage points — versus about 20 percentage points in the full sample.

We also note that our interpretation of the key fiscal-exposure results is supported not just by the larger substantive magnitudes for the sub-sample of progressive states. It is also supported by the evidence in Table 9 that the differences across education categories are now larger than before. The estimates in the final column of Table 9 are not just larger but even suggest a linear progression in the magnitude of the effect of fiscal exposure, moving up the four education groups from an estimated increase of 0 percentage points to 11,19 , and 33 , respectively.

Beyond Tables 7 through 9, we verified the robustness of our central results to many other checks (unreported for brevity). For example, we experimented with alternative measures of state fiscal exposure to immigration, such as expanding our reported measures to account for other researchers' interpretation of state responses to the 1996 federal welfare reform. ${ }^{31}$ We dropped individual states from our sample, in particular outlier immigration states shown in our figures such as California and New York. We added a number of additional non-economic individual characteristics that might help shape opinions, e.g., additional tolerance measures. ${ }^{32}$

\footnotetext{
${ }^{31}$ Zimmerman and Tumlin (1999) categorize certain states that did not reverse federal welfare restrictions on immigrants set in the 1996 reforms, and thus post-1996 had welfare regimes that were less generous to immigrants than to natives. We re-created Fiscal Exposure 1 by removing from the group of above-median welfare generosity in 2000 states that Zimmerman and Tumlin categorized as non-reversers.

32 One additional robustness check used the fact that in 1992 the NES asked respondents about whether "Hispanic" or "Asian" immigrants raise taxes. We did not find clear evidence that responses to this question were correlated with our fiscal-exposure measures. This lack of correlation may be for a number of reasons. One is that our analysis omitted relevant state determinants because estimations with state fixed effects were not possible on just one year of data. Another is that the frame of each question specified a particular immigrant group, so that respondents may not have truthfully revealed their beliefs so as not to appear biased against minorities. It is important to note that for our argument that fiscal considerations influence opinion formation about immigration, it is not necessary that all individuals have a clear reasoned belief that immigration has fiscal consequences. Individuals may simply have summary opinions consistent with their interests that depend on their consumption of information in their social networks and from the media (see Scheve and Slaughter 2001a for further discussion about how individuals may form policy opinions consistent with their interests despite low levels of information, but see also Tomz 2004 for an alternative view).
} 
The important result in Tables 5 through 9 is that fiscal exposure to immigration reduces support for freer immigration and that this effect is strongest among the high-skilled/high-income natives that pay a proportionately higher share of the fiscal costs. The magnitude of this fiscal cleavage is comparable to the effects of skill itself, from which we conclude that public-finance considerations are crucial in shaping opinions towards immigration policies.

\subsection{Trade Policy Preferences}

Table 10 reports our estimates of equation (3) for trade-policy preferences. Recall that based on our theoretical framework, we expect trade opinions to depend on pre-tax labor-market concerns but not on post-tax fiscal concerns. This is both because in theory trade does not have the necessary fiscal consequences that immigration does by virtue of population changes, and in practice because U.S. taxation and spending linked to trade policy is negligible.

The first two specifications in Table 10 are identical to Models I2 and I4 in Table 5 for immigration, except now the new dependent variable measures trade-policy opinions. Because these specifications measure state fiscal exposure to immigration, we do not expect to find any correlation here between fiscal concerns and trade opinions. The final two specifications use different fiscal measures that may be more relevant to possible fiscal impacts of trade. Fiscal Exposure 3 is defined using just the first criterion of Fiscal Exposure 1; that is, it identifies states with relatively high welfare generosity measured as above the national median welfare spending per native. Fiscal Exposure 4 is the same as Fiscal Exposure 3 but scores states on welfare spending divided by gross state product rather than number of natives. If state welfare programs provide some insurance to the pre-tax income pressures generated by freer trade, then individuals who feel they carry the burden of this welfare spending may be less inclined to support freer 
trade. As with immigration, given the progressivity of state fiscal regimes this disinclination may be strongest among the more-skilled, higher-income individuals.

The results across all four specifications in Table 10 replicate the findings in the literature that more-skilled individuals are less likely to support further trade restrictions. For an individual in a state with low fiscal impact, the coefficients for Model T1 imply that the difference between a college graduate and high-school drop out in the probability of favoring further trade restrictions is 0.37 (with a standard error of 0.05 ). This difference is identical for residents in high fiscal impact states, and is robust across all alternative specifications. This skills cleavage has been found by many others, and is consistent with the potential impact of trade on pre-tax labor income being an important factor in opinion formation over trade policy.

More important for this paper's focus on fiscal concerns, Table 10 shows no consistent variation in opinions over trade policy across states based on their fiscal regimes. The coefficients in Table 10 for interactions between the education variables and the fiscal-exposure measures are generally small and imprecisely estimated. We expected this for Fiscal Exposure 1 and 2, but also find this for Fiscal Exposure 3 and 4. The only exception is a statistically significant coefficient estimate on the interaction between College and Fiscal Exposure 4 but in unreported results this particular finding was not very robust.

This lack of a clear correlation between trade opinions and fiscal considerations, along with the opposite evidence for immigration in Tables 5 and 9 , is consistent with our overall argument that public-finance considerations appear to be crucial in shaping opinions towards alternative globalization strategies. Where public-finance matters can bite directly-in our data, for immigration but not trade — we see important impacts on individual opinions. 


\section{Conclusions}

This paper has examined the influence of public finance on individual preferences towards alternative globalization strategies. In the absence of distortionary tax and spending policies, freer immigration and trade for a country would often be supported by similar groups thanks to similar impacts on labor demand and thus labor income. But government policies that redistribute income may alter the distributional politics. Immigrants may pay taxes and receive public services. Imports, obviously, do neither of these. This suggests quite different political coalitions may organize around trade and immigration.

In this paper we developed a framework for examining how pre-tax and post-tax cleavages may differ across globalization strategies and also across fiscal jurisdictions. We then applied this framework to the case of individual immigration and trade preferences across U.S. states. The substantial variation both across states and over time in immigrant presence and welfare eligibility allows a rich examination of theoretical predictions.

We generated two main empirical findings. First, high exposure to immigrant fiscal pressures reduces support for freer immigration among natives, especially the more-skilled. The magnitude of this post-tax fiscal cleavage is comparable to the pre-tax labor-market effects of skill itself. Second, there is no public-finance variation in opinion over trade policy, consistent with the data that U.S. trade policy has negligible fiscal-policy impacts.

The evidence in this paper suggests that public-finance considerations are crucial in shaping opinions towards alternative globalization strategies. It is not just distributive politics in the labor market that feature prominently for these opinions, as much recent work has investigated. It is also distributive politics in the fiscal arena as well. 
We think that this insight may shed light on a number of important questions in international political economy. For example, even within the same policy domain the fiscal issues at stake can vary greatly and account for differences in the politics observed in different contexts. U.S. immigration policy was much more liberal a century ago than today. One source of this difference may be that, unlike today, a century ago the United States had virtually no social safety net. Fiscal considerations may also push in the opposite direction. In current immigration debates in Europe, concern over social spending on immigrants is balanced against the need to recruit workers whose tax payments could support state pension systems that face dangerous shortfalls from significantly aging populations.

But the most interesting application of our framework may be to help explain why countries choose different policy approaches toward different dimensions of international economic integration. It is has long been recognized that many countries have chosen liberal trade but restrictionist immigration policies. Perhaps even more striking is how liberal policies regulating foreign investment are compared to both trade and immigration. The explanation for different approaches no doubt involves many factors, but we think that future research examining the fiscal consequences of policy alternatives may help account for voter preferences and their role in explaining these policy combinations. 


\section{References}

Baker, Andy. 2003. "Why is Trade Reform so Popular in Latin America?" World Politics 55 (April): 423-55.

Beaulieu, Eugene. 2002. "Factor or Industry Cleavages in Trade Policy? An Empirical Test of the Stolper-Samuelson Theorem.” Economics and Politics Vol. 14 No. 2 (July):99-131.

Borjas, George J. 1999a. Heaven's Door: Immigration Policy and the American Economy. Princeton, N.J.: Princeton University Press.

Borjas, George J. 1999b. “The Economic Analysis of Immigration.” In Orley C. Ashenfelter and David Card, eds., Handbook of Labor Economics, Amsterdam: North-Holland, pp. 16971760 .

Borjas, George J. 2003. "Welfare Reform, Labor Supply, and Health Insurance in the Immigrant Population.” National Bureau of Economic Research Working Paper \#9781.

Borjas, George J., Richard B. Freeman, and Lawrence F. Katz. 1997. "How Much Do Immigration and Trade Affect Labor Market Outcomes?" Brookings Papers on Economic Activity 1: 1-90.

Borjas, George J., and Lynette Hilton. 1996. "Immigration and the Welfare State: Immigrant Participation in Means-Tested Entitlement Programs," Quarterly Journal of Economics, 111(2), pp. 575-604.

Card, David. 2001. "Immigrant Inflows, Native Outflows, and the Local Labor Market Impacts of Higher Immigration.” Journal of Labor Economics, 19 (1): 22-64.

Citrin, Jack, Donald Green, Christopher Muste, and Cara Wong. 1997. "Public Opinion Toward Immigration Reform: The Role of Economic Motivation." The Journal of Politics 59 (3): 858-81.

Feenstra, Robert C. (ed). 2000. The Impact of International Trade On Wages. Chicago: The University of Chicago Press.

Feenstra, Robert C., and Gordon H. Hanson. 2002. "Global Production and Inequality: A Survey of Trade and Wages," in James Harrigan (ed.) Handbook of International Trade, Basil Blackwell.

Fix, Michael, and Jeffrey Passel. 1999. “Trends in Citizens' and Noncitizens' Use of Public Benefits Following Welfare Reform, 1994-1997." Washington, DC: The Urban Institute.

Fix, Michael, and Jeffrey Passel. 2002. "The Scope and Impact of Welfare Reform's Immigrant Provisions." Washington, DC: The Urban Institute. 
Hainmueller, Jens, and Michael J. Hiscox. 2004a. "Educated Preferences: Explaining Attitudes Toward Immigration in Europe." Paper prepared for presentation at the Annual Meeting of the American Political Science Association.

Hainmueller, Jens, and Michael J. Hiscox. 2004b. "Learning to Love Globalization: The Effects of Education on Individual Attitudes Toward International Trade." Harvard University Mimeo.

Hanson, Gordon H. and Matthew J. Slaughter. 2002. "Labor-Market Adjustment in Open Economies: Evidence from U.S. States,” Journal of International Economics, 57 (1), pp. 3-29.

Hays, Jude, Sean Ehrlich, and Clint Peinhardt. Forthcoming. "Government Spending and Public Support for Trade in the OECD: An Empirical Test of the Embedded Liberalism Thesis." International Organization.

International Monetary Fund. 2004. Government Finance Statistics. Washington, D.C.

Kessler, Alan. 2001. "Immigration, Economic Insecurity, and the "Ambivalent" American Public.” Working Paper No. 41. Center for Comparative Immigration Studies, UCSD.

Jain, Sanjay, Devesh Kapur, and Sharun Mukand. 2004. "Outsourcing and International Labor Mobility: A Political Economy Analysis.” Paper presented at the Institute for World Economics, Kiel, Germany.

Kletzer, Lori, and Robert Litan. 2001. “A Prescription to Relieve Worker Anxiety.” Policy Brief \#01-2, Washington, D.C: Institute for International Economics.

Mayda, Anna Marie. 2004. "Who is Against Immigration?: A Cross-Country Investigation of Individual Attitudes toward Immigrants." Mimeograph.

Mayda, Anna Marie, and Dani Rodrik. 2002. "Why Are Some People (and Countries) More Protectionist Than Others?" NBER Working Paper No. 8461.

O’Rourke, Kevin, and Richard Sinnott. 2001. "The Determinants of Individual Trade Policy Preferences: International Survey Evidence." In Brookings Trade Forum: 2001, Collins, S. M. and Rodrik, D. (eds.). Washington, D.C.: Brookings.

O’Rourke, Kevin, and Richard Sinnott. 2003. "Migration Flows: Political Economy of Migration and the Empirical Challenges." Working Paper.

Rodrik, Dani. 1997. Has Globalization Gone Too Far? Washington, DC: Institute for International Economics.

Rodrik, Dani. 1998. "Why Do More Open Economies Have Bigger Governments?" Journal of Political Economy Vol. 106 No. 5:997-1032. 
Sapiro, Virginia, Steven J. Rosenstone, Warren E. Miller, and the National Election Studies. 1998. American National Election Studies, 1948-1997 [CD-ROM]. ICPSR ed. Ann Arbor, MI: Inter-university Consortium for Political and Social Research [producer and distributor].

Scheve, Kenneth F., and Matthew J. Slaughter. 2001a. Globalization and the Perceptions of American Workers. Washington DC: Institute for International Economics.

Scheve, Kenneth F., and Matthew J. Slaughter. 2001b. "What Determines Individual TradePolicy Preferences." Journal of International Economics, Vol. 54 No. 2 (August):267-292.

Scheve, Kenneth F., and Matthew J. Slaughter. 2001c. "Labor-Market Competition and Individual Preferences Over Immigration Policy." Review of Economics and Statistics, Vol. 83 No. 1 (February):133-145.

Scheve, Kenneth F. and Matthew J. Slaughter. 2004. "Economic Insecurity and the Globalization of Production." American Journal of Political Science Vol. 48 No. 4 (October).

Scheve, Kenneth F. and Matthew J. Slaughter. Forthcoming. "Public Opinion, International Integration, and the Welfare State." In Samuel Bowles, Pranab Bardhan, and Michael Wallerstein (eds.) Globalization and Egalitarian Redistribution. Princeton, NJ: Princeton University Press.

Smith, J.P. and Edmonston, B (eds.). 1997. The New Americans: Economic Demographic, and Fiscal Effects of Immigration. National Academy Press: Washington, D.C.

Stolper, Wolfgang, and Paul Samuelson. 1941. "Protection and Real Wages." Review of Economic Studies 9: 58-73.

Tomz, Michael. 2004. "Interests, Information, and the Domestic Politics of International Agreements.” Stanford University Mimeo.

United States Trade Representative. 2003. "Revenue Implications of Trade Liberalization: Communication from the United States." Communication to World Trade Organization, dated April 10.

Zimmermann, Wendy, and Karen Tumlin. 1999. "Patchwork Policies: State Assistance for Immigrants under Welfare Reform.” The Urban Institute Occasional Paper Number 24. 


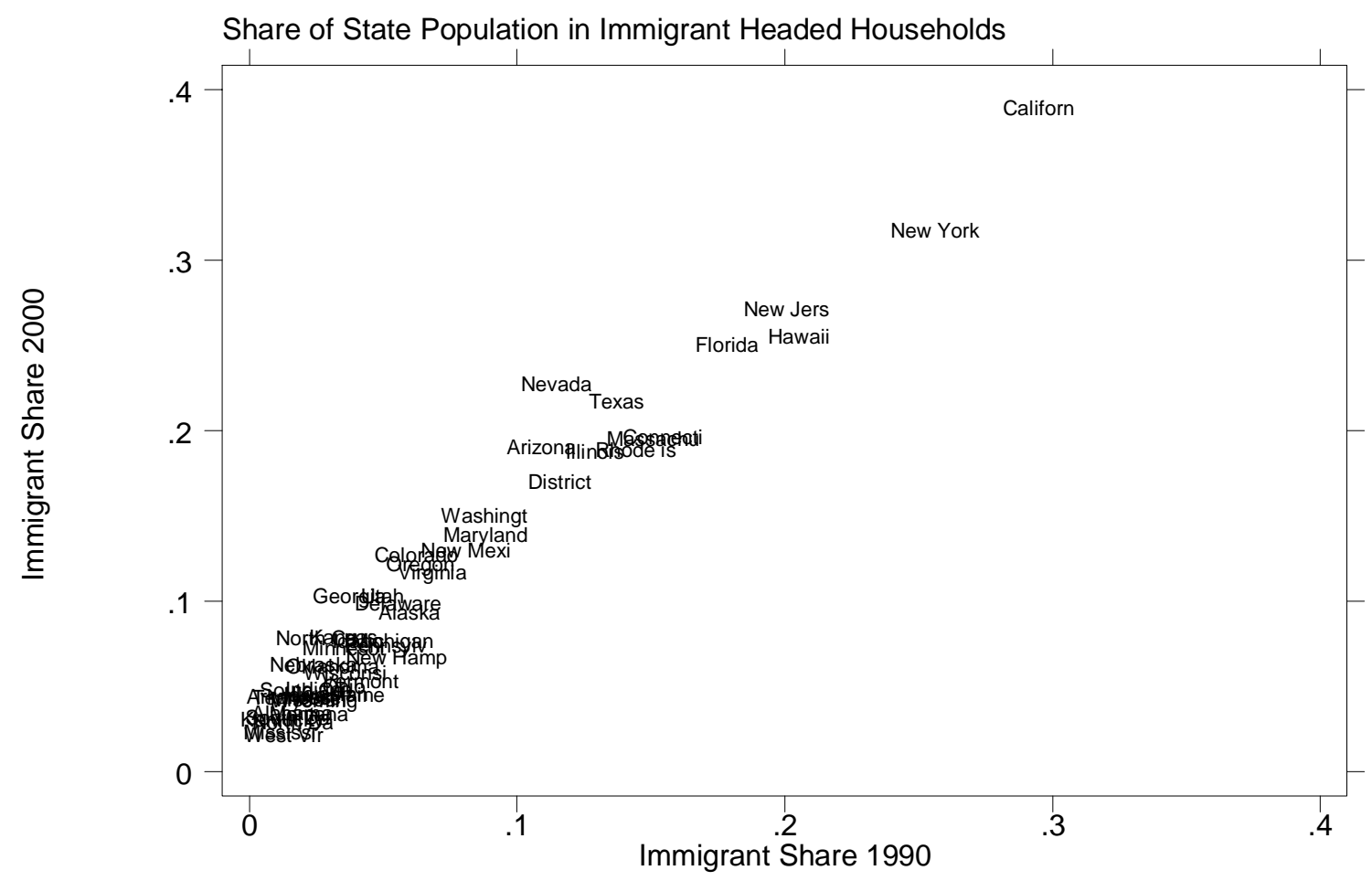

Figure 1

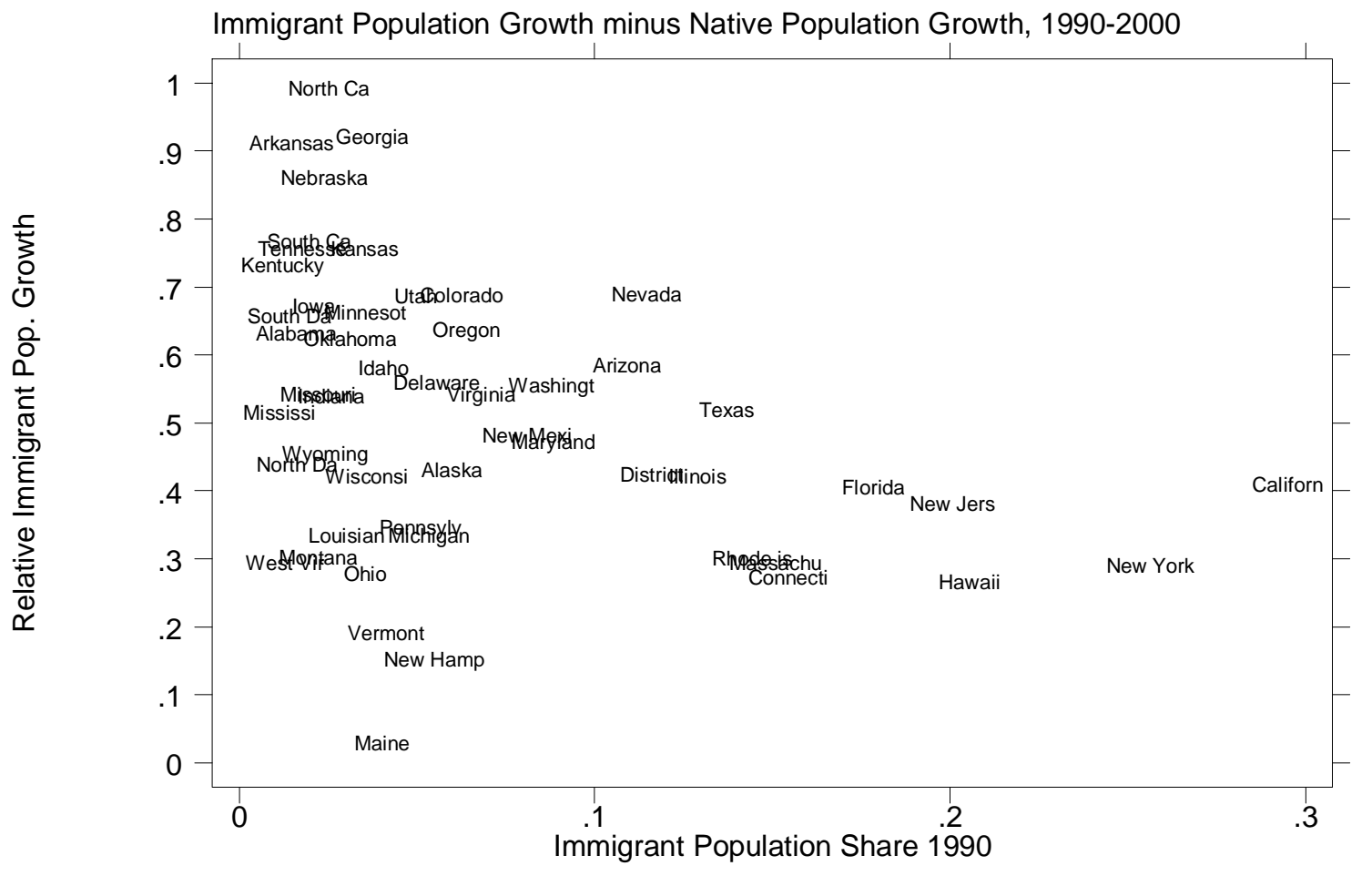

Figure 2 


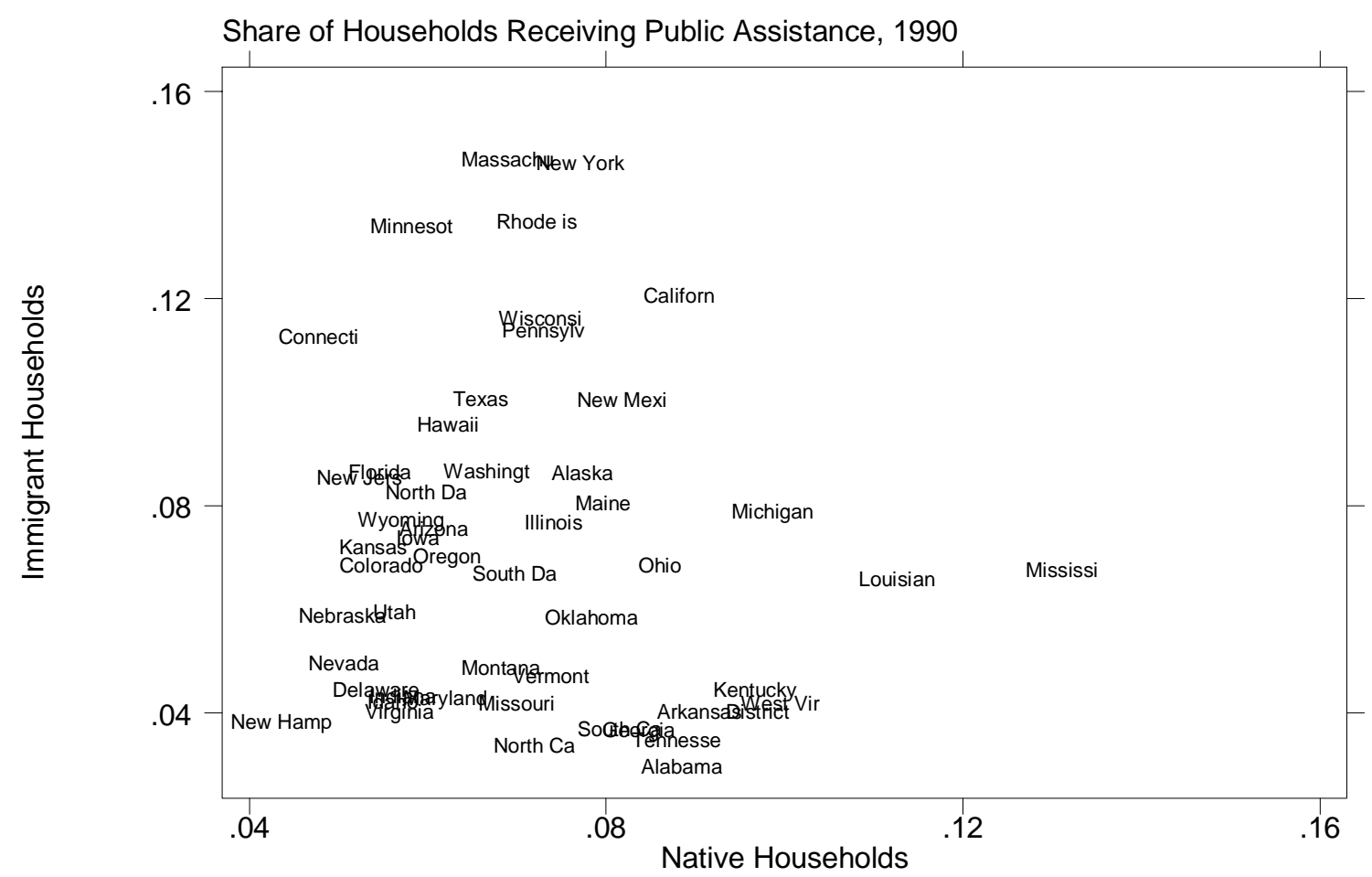

\section{Figure 3a}

Share of Households Receiving Public Assistance, 2000

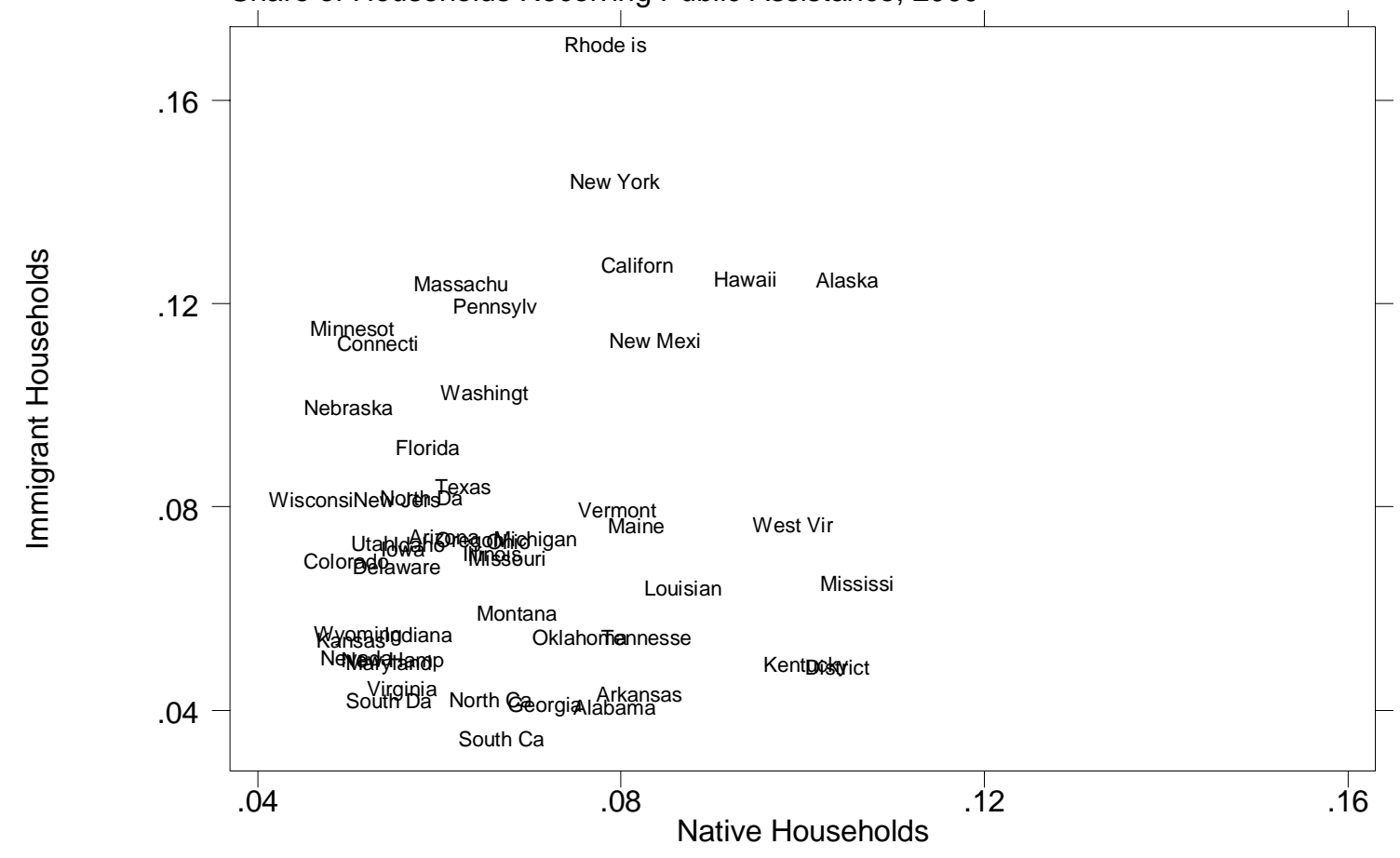

\section{Figure 3b}




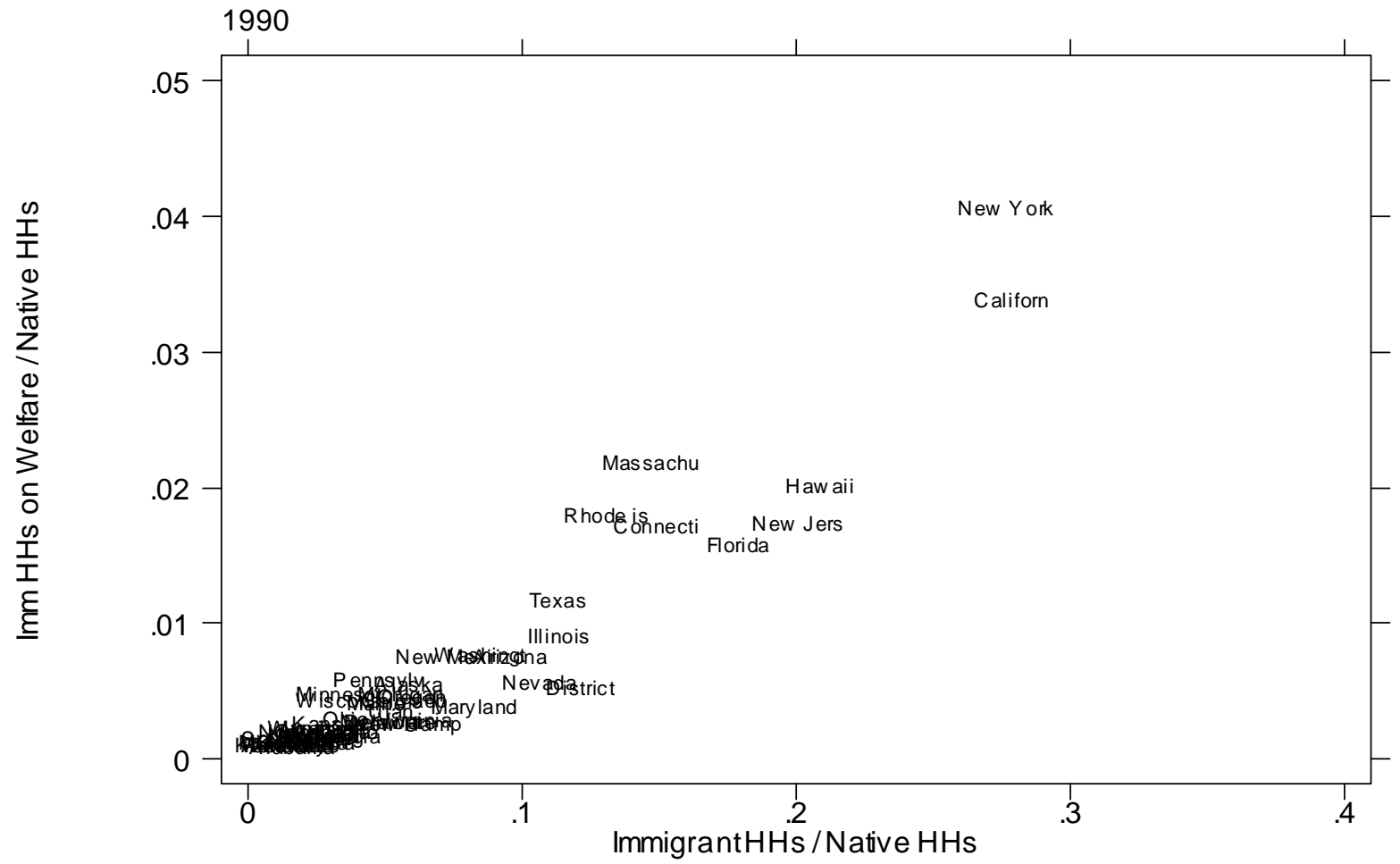

Figure 4a

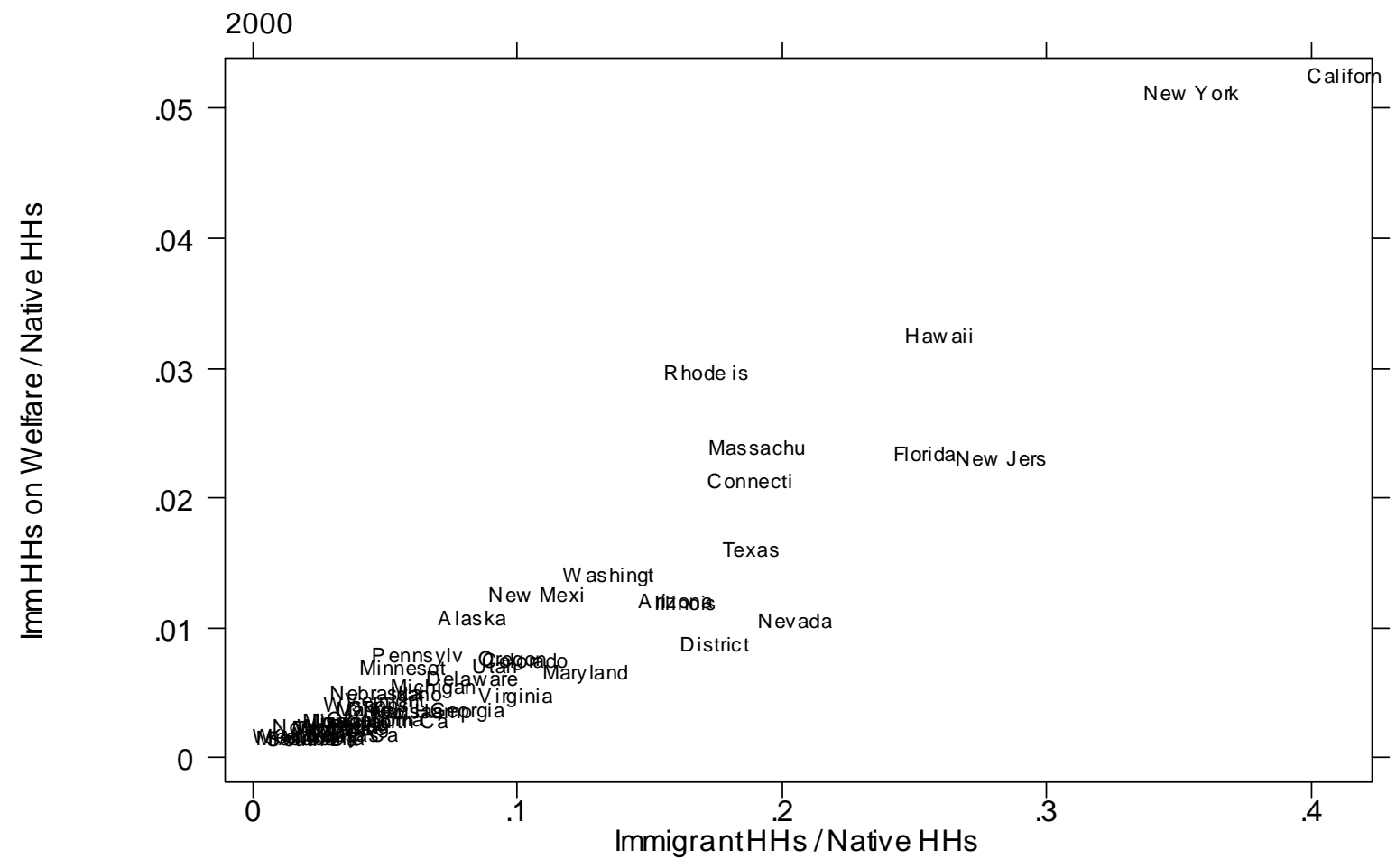

Figure 4b 


\section{Table 1: Support for Decreased Immigration by Education}

\begin{tabular}{ccccc}
\hline $\begin{array}{c}\text { No High } \\
\text { School }\end{array}$ & $\begin{array}{c}\text { High } \\
\text { School }\end{array}$ & $\begin{array}{c}\text { Some } \\
\text { College }\end{array}$ & $\begin{array}{c}\text { College } \\
\text { Graduate }\end{array}$ & Total \\
\hline \multirow{2}{*}{0.541} & 0.568 & 0.500 & 0.386 & 0.503 \\
\hline
\end{tabular}

Table 2: Support for Trade Restrictions by Education

\begin{tabular}{ccccc}
\hline $\begin{array}{c}\text { No High } \\
\text { School }\end{array}$ & $\begin{array}{c}\text { High } \\
\text { School }\end{array}$ & $\begin{array}{c}\text { Some } \\
\text { College }\end{array}$ & $\begin{array}{c}\text { College } \\
\text { Graduate }\end{array}$ & Total \\
\hline 0.722 & 0.706 & 0.588 & 0.394 & 0.591 \\
\hline
\end{tabular}

Notes: Table 1 reports the fraction of native-born individuals reporting that they would prefer immigration to be decreased (by a little or by a lot) in the NES surveys for 1992 and 2000. Table 2 reports the fraction of native-born individuals reporting support for trade restrictions also for 1992 and 2000. No high school refers to those with less than 12 years of education, high school refers to those with 12 years of education, some college to those with 13-15 years of education, and college graduates to those with 16 or more years of education. Summary statistics are calculated using the NES sampling weights. 
Table 3: Support for Decreased Immigration by Education and Fiscal Exposure to Immigrants

\begin{tabular}{cccccc}
\hline $\begin{array}{c}\text { Fiscal Exposure } \\
\text { Measure }\end{array}$ & Fiscal Exposure & $\begin{array}{c}\text { No High } \\
\text { School }\end{array}$ & $\begin{array}{c}\text { High } \\
\text { School }\end{array}$ & $\begin{array}{c}\text { Some } \\
\text { College }\end{array}$ & $\begin{array}{c}\text { College } \\
\text { Graduate }\end{array}$ \\
\hline \multirow{2}{*}{ Fiscal Exposure 1 } & Low & 0.537 & 0.571 & 0.507 & 0.362 \\
& High & 0.625 & 0.558 & 0.461 & 0.420 \\
& & & & & \\
Fiscal Exposure 2 & Low & 0.498 & 0.572 & 0.516 & 0.361 \\
& High & 0.658 & 0.557 & 0.464 & 0.435 \\
\hline
\end{tabular}

Table 4: Support for Trade Restrictions by Education and Fiscal Exposure to Immigrants

\begin{tabular}{cccccc}
\hline $\begin{array}{c}\text { Fiscal Exposure } \\
\text { Measure }\end{array}$ & Fiscal Exposure & $\begin{array}{c}\text { No High } \\
\text { School }\end{array}$ & $\begin{array}{c}\text { High } \\
\text { School }\end{array}$ & $\begin{array}{c}\text { Some } \\
\text { College }\end{array}$ & $\begin{array}{c}\text { College } \\
\text { Graduate }\end{array}$ \\
\hline \multirow{2}{*}{ Fiscal Exposure 1 } & Low & 0.748 & 0.719 & 0.590 & 0.383 \\
& High & 0.662 & 0.674 & 0.560 & 0.418 \\
& & & & & \\
Fiscal Exposure 2 & Low & 0.728 & 0.719 & 0.606 & 0.392 \\
& High & 0.707 & 0.674 & 0.548 & 0.397 \\
\hline
\end{tabular}

Notes: Table 3 reports the fraction of native-born individuals reporting that they would prefer immigration to be decreased (by a little or by a lot) in the NES surveys for 1992 and 2000. Table 4 reports the fraction of native-born individuals reporting support for trade restrictions also for 1992 and 2000. States with high immigrant welfare costs have values of Fiscal Exposure 1 (or Fiscal Exposure 2) equal to 1. No high school refers to those with less than 12 years of education, high school refers to those with 12 years of education, some college to those with 13-15 years of education, and college graduates to those with 16 or more years of education. Summary statistics are calculated using the NES sampling weights. 
Table 5: Immigration-Policy Preferences, Benchmark Specifications

\begin{tabular}{|c|c|c|c|c|}
\hline & \multicolumn{2}{|c|}{ Fiscal Exposure 1} & \multicolumn{2}{|c|}{ Fiscal Exposure 2} \\
\hline & Model I1 & Model I2 & Model I3 & Model I4 \\
\hline \multirow[t]{3}{*}{ High School } & 0.182 & 0.168 & 0.211 & 0.206 \\
\hline & $(0.101)$ & $(0.107)$ & $(0.095)$ & $(0.103)$ \\
\hline & 0.071 & 0.118 & 0.027 & 0.046 \\
\hline \multirow[t]{3}{*}{ Some College } & 0.047 & 0.027 & 0.102 & 0.092 \\
\hline & $(0.097)$ & $(0.098)$ & $(0.100)$ & $(0.104)$ \\
\hline & 0.626 & 0.783 & 0.309 & 0.379 \\
\hline \multirow[t]{3}{*}{ College } & -0.347 & -0.356 & -0.298 & -0.295 \\
\hline & $(0.119)$ & $(0.130)$ & $(0.116)$ & $(0.127)$ \\
\hline & 0.004 & 0.006 & 0.011 & 0.020 \\
\hline \multirow{3}{*}{ No High School * Immigration } & 0.445 & 0.474 & 0.365 & 0.667 \\
\hline & $(0.141)$ & $(0.173)$ & $(0.257)$ & $(0.270)$ \\
\hline & 0.002 & 0.006 & 0.155 & 0.014 \\
\hline \multirow[t]{3}{*}{ High School * Immigration } & -0.016 & 0.034 & -0.012 & 0.248 \\
\hline & $(0.117)$ & $(0.136)$ & $(0.122)$ & $(0.140)$ \\
\hline & 0.889 & 0.802 & 0.920 & 0.077 \\
\hline \multirow[t]{3}{*}{ Some College $*$ Immigration } & -0.098 & -0.033 & -0.143 & 0.116 \\
\hline & $(0.094)$ & $(0.097)$ & $(0.088)$ & $(0.151)$ \\
\hline & 0.297 & 0.734 & 0.105 & 0.439 \\
\hline \multirow[t]{3}{*}{ College * Immigration } & -0.078 & -0.016 & -0.183 & 0.043 \\
\hline & $(0.111)$ & $(0.128)$ & $(0.115)$ & $(0.165)$ \\
\hline & 0.480 & 0.900 & 0.112 & 0.796 \\
\hline \multirow[t]{3}{*}{ No High School * Fiscal Exposure (1 or 2) } & -0.090 & 0.246 & 0.102 & 0.189 \\
\hline & $(0.200)$ & $(0.169)$ & $(0.264)$ & $(0.259)$ \\
\hline & 0.652 & 0.147 & 0.698 & 0.465 \\
\hline \multirow[t]{3}{*}{ High School * Fiscal Exposure (1 or 2) } & -0.008 & 0.303 & -0.011 & 0.144 \\
\hline & $(0.141)$ & $(0.130)$ & $(0.137)$ & $(0.136)$ \\
\hline & 0.954 & 0.020 & 0.936 & 0.288 \\
\hline \multirow[t]{3}{*}{ Some College * Fiscal Exposure (1 or 2) } & -0.036 & 0.237 & -0.003 & 0.138 \\
\hline & $(0.089)$ & $(0.109)$ & $(0.082)$ & $(0.110)$ \\
\hline & 0.686 & 0.030 & 0.974 & 0.211 \\
\hline \multirow[t]{3}{*}{ College $*$ Fiscal Exposure (1 or 2) } & 0.219 & 0.490 & 0.347 & 0.526 \\
\hline & $(0.118)$ & $(0.145)$ & $(0.127)$ & $(0.117)$ \\
\hline & 0.063 & 0.001 & 0.006 & 0.000 \\
\hline State Fixed Effects & No & Yes & No & Yes \\
\hline Baseline Control Variables & Yes & Yes & Yes & Yes \\
\hline Observations & 2,978 & 2,978 & 3,117 & 3,117 \\
\hline Log-likelihood & $-2,021.13$ & $-1,995.44$ & $-2,115.0$ & $-2,088.7$ \\
\hline \multicolumn{5}{|c|}{$\begin{array}{l}\text { Notes: This table reports coefficient estimates for probit regressions on native individuals from the } 1992 \text { and } 2000 \\
\text { NES surveys. The dependent variable is Immigration Opinion, equal to one for respondents who support further } \\
\text { restricting immigration and zero otherwise. The baseline control variables are Age, Age Squared, Female, } \\
\text { Hispanic, State Unemployment, a year indicator variable for 2000, and a constant. Each cell reports a coefficient } \\
\text { estimate, a state-clustered robust standard error in parentheses, and a p-value. Observations are weighted using } \\
\text { sampling weights from the NES data. }\end{array}$} \\
\hline
\end{tabular}


Table 6: Estimated Effect of Increasing Fiscal Exposure to Immigration on the Probability of Supporting Immigration Restrictions

\begin{tabular}{|c|c|c|}
\hline $\begin{array}{c}\text { Fiscal Exposure } \\
\text { Measure }\end{array}$ & Education Level & $\begin{array}{c}\text { Change in Probability of } \\
\text { Supporting Immigration } \\
\text { Restrictions }\end{array}$ \\
\hline \multirow[t]{5}{*}{ Fiscal Exposure 1} & No High School & $\begin{array}{c}0.097 \\
(0.066)\end{array}$ \\
\hline & High School & $\begin{array}{c}0.119 \\
(0.050)\end{array}$ \\
\hline & Some College & $\begin{array}{c}0.094 \\
(0.043)\end{array}$ \\
\hline & College & 0.189 \\
\hline & & $(0.053)$ \\
\hline \multirow[t]{4}{*}{ Fiscal Exposure 2} & No High School & $\begin{array}{c}0.075 \\
(0.102)\end{array}$ \\
\hline & High School & $\begin{array}{c}0.057 \\
(0.054)\end{array}$ \\
\hline & Some College & $\begin{array}{c}0.055 \\
(0.044)\end{array}$ \\
\hline & College & $\begin{array}{c}0.202 \\
(0.042)\end{array}$ \\
\hline
\end{tabular}

Notes: Based on the estimates from Model I2 and I4, this table reports the consequences for the probability of supporting immigration restrictions of changing from a state in which fiscal exposure to immigration is low (Fiscal Exposure 1 or 2 equals 0) to a state in which it is high (Fiscal Exposure 1 or 2 equals 1) for individuals at different skill levels. The standard error of this estimate is reported in parentheses. 
Table 7: Immigration-Policy Preferences, Additional Control Variables

\begin{tabular}{|c|c|c|}
\hline & $\frac{\text { Fiscal Exposure } 1}{\text { Model I5 }}$ & $\frac{\text { Fiscal Exposure } 2}{\text { Model I6 }}$ \\
\hline High School & $\begin{array}{c}0.142 \\
(0.159)\end{array}$ & $\begin{array}{l}0.146 \\
(0.152)\end{array}$ \\
\hline Some College & $\begin{array}{l}-0.022 \\
(0.150)\end{array}$ & $\begin{array}{l}-0.006 \\
(0.142)\end{array}$ \\
\hline College & $\begin{array}{l}-0.304 \\
(0.169)\end{array}$ & $\begin{array}{l}-0.289 \\
(0.160)\end{array}$ \\
\hline No High School * Immigration & $\begin{array}{c}0.507 \\
(0.234)\end{array}$ & $\begin{array}{c}0.662 \\
(0.374)\end{array}$ \\
\hline High School * Immigration & $\begin{array}{c}0.038 \\
(0.171)\end{array}$ & $\begin{array}{c}0.238 \\
(0.172)\end{array}$ \\
\hline Some College * Immigration & $\begin{array}{l}-0.019 \\
(0.106)\end{array}$ & $\begin{array}{l}0.167 \\
(0.157)\end{array}$ \\
\hline College * Immigration & $\begin{array}{l}-0.133 \\
(0.112)\end{array}$ & $\begin{array}{l}-0.024 \\
(0.155)\end{array}$ \\
\hline No High School * Fiscal Exposure (1 or 2) & $\begin{array}{c}0.273 \\
(0.264)\end{array}$ & $\begin{array}{c}0.287 \\
(0.355)\end{array}$ \\
\hline High School * Fiscal Exposure (1 or2) & $\begin{array}{c}0.331 \\
(0.144)\end{array}$ & $\begin{array}{c}0.276 \\
(0.136)\end{array}$ \\
\hline Some College * Fiscal Exposure (1 or 2) & $\begin{array}{c}0.222 \\
(0.134)\end{array}$ & $\begin{array}{c}0.182 \\
(0.094)\end{array}$ \\
\hline College * Fiscal Exposure (1 or 2) & $\begin{array}{c}0.529 \\
(0.144)\end{array}$ & $\begin{array}{c}0.603 \\
(0.131)\end{array}$ \\
\hline Unemployed & $\begin{array}{l}-0.281 \\
(0.145)\end{array}$ & $\begin{array}{l}-0.271 \\
(0.143)\end{array}$ \\
\hline Union Member & $\begin{array}{c}0.165 \\
(0.108)\end{array}$ & $\begin{array}{c}0.164 \\
(0.107)\end{array}$ \\
\hline Government Employee & $\begin{array}{l}-0.015 \\
(0.065)\end{array}$ & $\begin{array}{l}-0.006 \\
(0.062)\end{array}$ \\
\hline Partisanship & $\begin{array}{c}0.030 \\
(0.017)\end{array}$ & $\begin{array}{c}0.032 \\
(0.017)\end{array}$ \\
\hline Ideology & $\begin{array}{c}0.046 \\
(0.024)\end{array}$ & $\begin{array}{c}0.050 \\
(0.024)\end{array}$ \\
\hline Tolerance & $\begin{array}{l}-0.044 \\
(0.022)\end{array}$ & $\begin{array}{l}-0.052 \\
(0.023)\end{array}$ \\
\hline Isolationism & $\begin{array}{c}0.461 \\
(0.066)\end{array}$ & $\begin{array}{c}0.463 \\
(0.065)\end{array}$ \\
\hline State Fixed Effects & Yes & Yes \\
\hline Baseline Control Variables & Yes & Yes \\
\hline $\begin{array}{l}\text { Observations } \\
\text { Log-likelihood }\end{array}$ & $\begin{array}{c}2,201 \\
-1,419.25\end{array}$ & $\begin{array}{c}2,277 \\
-1,463.65\end{array}$ \\
\hline $\begin{array}{l}\text { Notes: This table reports coefficient estima } \\
1992 \text { and } 2000 \text { NES surveys. The depen } \\
\text { respondents who support further restricting } \\
\text { variables are Age, Age Squared, Female, Hi } \\
\text { 2000, and a constant. Each cell reports a } \\
\text { error in parentheses. Observations are weig }\end{array}$ & $\begin{array}{l}\text { it regressions on na } \\
\text { le is Immigration } O \\
\text { on and zero otherwi } \\
\text { e Unemployment, a y } \\
\text { estimate and a state- } \\
\text { ampling weights fror }\end{array}$ & $\begin{array}{l}\text { e individuals from the } \\
\text { iion, equal to one for } \\
\text { The baseline control } \\
r \text { indicator variable for } \\
\text { stered robust standard } \\
\text { he NES data. }\end{array}$ \\
\hline
\end{tabular}


Table 8: Immigration-Policy Preferences, Income Specifications

\begin{tabular}{|c|c|c|}
\hline & Fiscal Exposure 1 & Fiscal Exposure 2 \\
\hline & Model I7 & Model I8 \\
\hline \multirow[t]{3}{*}{ Income Quartile 2} & 0.137 & 0.163 \\
\hline & $(0.096)$ & $(0.092)$ \\
\hline & 0.156 & 0.078 \\
\hline \multirow[t]{3}{*}{ Income Quartile 3} & 0.184 & 0.173 \\
\hline & $(0.124)$ & $(0.113)$ \\
\hline & 0.137 & 0.128 \\
\hline \multirow[t]{3}{*}{ Income Quartile 4} & -0.140 & -0.106 \\
\hline & $(0.098)$ & $(0.098)$ \\
\hline & 0.152 & 0.276 \\
\hline \multirow[t]{3}{*}{ Income Quartile $1 *$ Immigration } & 0.037 & 0.083 \\
\hline & $(0.151)$ & $(0.176)$ \\
\hline & 0.806 & 0.639 \\
\hline \multirow[t]{3}{*}{ Income Quartile $2 *$ Immigration } & 0.055 & 0.278 \\
\hline & $(0.115)$ & $(0.163)$ \\
\hline & 0.633 & 0.088 \\
\hline \multirow[t]{3}{*}{ Income Quartile $3 *$ Immigration } & 0.171 & 0.305 \\
\hline & $(0.130)$ & $(0.167)$ \\
\hline & 0.188 & 0.068 \\
\hline \multirow[t]{3}{*}{ Income Quartile $4 *$ Immigration } & -0.097 & -0.076 \\
\hline & $(0.107)$ & $(0.151)$ \\
\hline & 0.366 & 0.616 \\
\hline \multirow[t]{3}{*}{ Income Quartile $1 *$ Fiscal Exposure (1 or 2) } & 0.220 & 0.235 \\
\hline & $(0.162)$ & $(0.163)$ \\
\hline & 0.175 & 0.150 \\
\hline \multirow[t]{3}{*}{ Income Quartile 2 * Fiscal Exposure (1 or 2) } & 0.284 & 0.003 \\
\hline & $(0.169)$ & $(0.147)$ \\
\hline & 0.092 & 0.986 \\
\hline \multirow[t]{3}{*}{ Income Quartile $3 *$ Fiscal Exposure (1 or 2) } & 0.262 & 0.152 \\
\hline & $(0.120)$ & $(0.157)$ \\
\hline & 0.029 & 0.334 \\
\hline \multirow[t]{3}{*}{ Income Quartile $4 *$ Fiscal Exposure (1 or 2) } & 0.421 & 0.413 \\
\hline & $(0.134)$ & $(0.150)$ \\
\hline & 0.002 & 0.006 \\
\hline State Fixed Effects & Yes & Yes \\
\hline Baseline Control Variables & Yes & Yes \\
\hline Observations & 2,734 & 2,867 \\
\hline Log-likelihood & $-1,846.18$ & $-1,936.72$ \\
\hline \multicolumn{3}{|c|}{$\begin{array}{l}\text { Notes: This table reports coefficient estimates for probit regressions on native individuals from the } 1992 \text { and } 2000 \\
\text { NES surveys. The dependent variable is Immigration Opinion, equal to one for respondents who support further } \\
\text { restricting immigration and zero otherwise. The baseline control variables are Age, Age Squared, Female, } \\
\text { Hispanic, State Unemployment, a year indicator variable for } 2000 \text {, and a constant. Each cell reports a coefficient } \\
\text { estimate, a state-clustered robust standard error in parentheses, and a p-value. Observations are weighted using } \\
\text { sampling weights from the NES data. }\end{array}$} \\
\hline
\end{tabular}


Table 9: Immigration-Policy Preferences, Benchmark Specifications in States with Relatively Progressive Tax Systems

\begin{tabular}{|c|c|c|}
\hline \multirow[b]{2}{*}{ Fiscal Exposure Measure } & $\begin{array}{c}\text { Progressive Tax } \\
\text { System Measure } 1\end{array}$ & $\begin{array}{c}\text { Progressive Tax } \\
\text { System Measure } 2\end{array}$ \\
\hline & Model I2 & Model I2 \\
\hline \multirow[t]{3}{*}{ No High School * Fiscal Exposure 1} & 0.285 & -0.229 \\
\hline & $(0.235)$ & $(0.299)$ \\
\hline & 0.224 & 0.444 \\
\hline \multirow[t]{3}{*}{ High School * Fiscal Exposure 1} & 0.382 & 0.290 \\
\hline & $(0.150)$ & $(0.219)$ \\
\hline & 0.011 & 0.185 \\
\hline \multirow[t]{3}{*}{ Some College * Fiscal Exposure 1} & 0.315 & 0.477 \\
\hline & $(0.056)$ & $(0.144)$ \\
\hline & 0.000 & 0.001 \\
\hline \multirow[t]{3}{*}{ College ${ }^{*}$ Fiscal Exposure 1} & 0.803 & 0.905 \\
\hline & $(0.064)$ & $(0.104)$ \\
\hline & 0.000 & 0.000 \\
\hline Education Variables & Yes & Yes \\
\hline Education * Immigration Variables & Yes & Yes \\
\hline State Fixed Effects & Yes & Yes \\
\hline Baseline Control Variables & Yes & Yes \\
\hline Observations & 1,293 & 1,752 \\
\hline Log-likelihood & -857.36 & $-1,161.03$ \\
\hline \multicolumn{3}{|c|}{$\begin{array}{l}\text { Notes: This table reports coefficient estimates for probit regressions on native individuals in } \\
\text { states with relatively progressive tax systems from the } 1992 \text { and } 2000 \text { NES surveys. } \\
\text { Progressive Tax System Measure } 1 \text { is all states with above median values of the ratio of the top } \\
\text { income tax rate to the bottom rate. Progressive Tax System Measure } 2 \text { is all states with above } \\
\text { median values of the ratio of income tax revenue to total revenue. The dependent variable is } \\
\text { Immigration Opinion, equal to one for respondents who support further restricting immigration } \\
\text { and zero otherwise. The baseline control variables are Age, Age Squared, Female, Hispanic, } \\
\text { State Unemployment, a year indicator variable for } 2000 \text {, and a constant. Each cell reports a } \\
\text { coefficient estimate, a state-clustered robust standard error in parentheses, and a p-value. } \\
\text { Observations are weighted using sampling weights from the NES data. }\end{array}$} \\
\hline
\end{tabular}


